Revista de Estudios Histórico-Jurídicos

[Sección Historia del Derecho Español]

XXXIV (Valparaíso, Chile, 2012)

[pp. 277 - 319]

\title{
HiSTORIA DEL DERECHO MEDIOAMBIENTAL: LA TUTELA DE LAS AGUAS EN LAS FUENTES JURÍDICAS CASTELLANAS DE LA EDAD MODERNA*
}

\author{
[History of Environmental Law: Water Tutelage in the Castilian Legal Sources \\ of the Modern Age]
}

\author{
Patricia Zambrana Moral** \\ Universidad de Málaga, España
}

\begin{abstract}
RESUMEN
Se efectúa un análisis de algunas disposiciones del Derecho castellano de la Edad Moderna dirigidas a la protección de las aguas como factor medioambiental frente a la contaminación. En esta época se advierte una preocupación, cada vez mayor, por la limpieza de fuentes, pozos y acequias, por el alcantarillado y la canalización de las aguas fecales y por delimitar las competencias de las autoridades encargadas del control de la limpieza de las ciudades. Normalmente, las cuestiones relativas a las aguas, a su cuidado, mantenimiento, limpieza y protección frente a elementos contaminantes se solían
\end{abstract}

\begin{abstract}
This work analyzes some provisions of Modern Age Castilian Law aimed at protecting the water as an environmental source of contamination. At those times we can see an increasing concern for cleaning fountains, wells and irrigation ditches, for the sewage system and channeling the sewage water as well as for delimiting the competence of the authorities in charge of controlling the cleaning of the cities. Commonly, the matters related to the water, its care, maintenance, cleaning and protection against polluting agents used to be compiled in local provisions, especially in municipal re-
\end{abstract}

* El presente trabajo ha sido realizado en el seno de los proyectos: Derecho Europeo uniforme de contratos maritimos: Fundamentos históricos. Implicaciones medioambientales y económicas (P09SEJ-4827. Proyecto de Excelencia de la Junta de Andalucía); Acción urbanizadora y Derecho urbanistico romano: ordenación del territorio, urbanismo, vivienda y medio ambiente (P08-SEJ3923. Proyecto de Excelencia de la Junta de Andalucía). Por lo demás, véase nuestro trabajo titulado: La protección de las aguas frente a la contaminación y otros aspectos medio-ambientales en el derecho romano y en el derecho castellano medieval, en Revista de Derecho de la Pontificia Universidad Católica de Valparaíso, 37 (Valparaíso, Chile, $2^{\circ}$ semestre de 2011).

** Profesora titular de Historia del Derecho y de las Instituciones de la Facultad de Derecho de la Universidad de Málaga. Dirección postal: Boulevard Louis Pasteur, No 24, Campus de Teatinos, 29071 Málaga, España. Correo electrónico: pzambrana@uma.es 
recoger en disposiciones de carácter local, sobre todo en ordenanzas municipales que eran las que se ocupaban de velar por aspectos relacionados con el medio ambiente desde el punto de vista higiénico-sanitario o de salud pública. Así, nos ocupamos de diversas ordenanzas municipales. Dentro del Derecho general hemos examinado la tutela de las aguas en el "Ordenamiento de Montalvo", en la "Nueva" y en la Novísima Recopilación.

\section{Palabras clave}

Aguas - Medio Ambiente - Contaminación - Historia del Derecho ambiental - Derecho moderno. gulations regarding environmental aspects from a hygiene/sanitary or public health point of view. Thus, we focus on several municipal regulations. Within the context of the General Law, we examine the water protection in the "Montalvo Regulations", in the "New" Compilation and the Novisima Recopilación.

KEYWORDS

Water - Environment - Contamination - History of Environmental Law - Modern Law

RECiBIDO el 4 de mayo y ACEPTADO el 9 de junio de 2012

\section{INTRODUCCIÓN}

En el Derecho histórico han existido disposiciones encaminadas a proteger el entorno y, en concreto, a evitar daños en el agua como uno de los elementos del mismo ${ }^{1}$, y ello a pesar del carácter novedoso y relativamente reciente de la tutela medioambiental desde el punto de vista jurídico y, por ende, de lo que hoy entendemos por Derecho ambiental ${ }^{2}$. La interacción del hombre con su hábitat

\footnotetext{
${ }^{1}$ Sobre la contaminación del agua en el mundo antiguo y su régimen sancionador, véase Solidoro MaruotTi, Laura, La tutela dell'ambiente nella sua evoluzione storica. L'esperienza del mondo antico (Torino, Giappichelli, 2009), pp. 58-66. En general, respecto a la historia del medio ambiente véanse: GonZÁlez de Molina, Manuel, Historia y medio ambiente (Madrid, Eudema, 1993); Federovisky, Sergio, Historia del medio ambiente (Buenos Aires, editorial Capital Intelectual, 2007); Hornborg, Alf; McNeill, J. R - MartíneZ-Alier, Joan (editores), Rethinking Environmental History: World-System History and Global Environmental Change (Lanham, Altamira Press, 2007) y, centrado en la historia jurídica americana: CALLIES, David L. Historic Preservation Law in the United States (Washington, D. C., Enviromental Law Institute, 2002).

${ }^{2}$ Véanse: Falbo, Aníbal José, Derecho ambiental (La Plata, Librería Editora Platense, 2009); Roche, Catherine, L'essentiel du droit de l'environnement (Paris, Gualino, 2009). El "Derecho ambiental” es la rúbrica por la que opta Martín Mateo, Ramón, Tratado de Derecho Ambiental (Madrid, Trivium, 1991), I, p. 80 (3a edición revisada y puesta al día, Cizur Menor, Aranzadi, 2003). El primer texto internacional que aborda el problema medioambiental y lo define es la Declaración de la Conferencia de las Naciones Unidas sobre el Medio Ambiente humano de Estocolmo (5-16 de junio de 1972). Históricamente, no se puede hablar de un Derecho ambiental sino que las normas que analizaremos y que, desde una perspectiva actual, nos parecen claramente medioambientales se ubicaban en otros sectores del ordenamiento jurídico (ordenación del territorio, urbanismo, sanidad, propiedad, servidumbre, relaciones
} 
es una constante desde la más remota antigüedad y ha ocasionado un indiscutible deterioro del mismo, siendo necesario imponer límites jurídicamente, sobre todo, a partir de la aparición de las ciudades ${ }^{3}$. No obstante, nuestra finalidad no es constatar el menoscabo sufrido por el medio ambiente a lo largo de la historia, lo que es una evidencia, sino centrarnos en algunas disposiciones o textos jurídicos relevantes o representativos del Derecho castellano de la Edad Moderna dirigidos a velar por las aguas como componente medioambiental y a protegerlas frente a la contaminación ${ }^{4}$. Como en otras ocasiones ${ }^{5}$, partimos de un concepto genérico de medio ambiente, integrado por todos los elementos que nos rodean (incluyendo el agua) ${ }^{6}$.

Es importante precisar que, históricamente, la protección jurídica del medio ambiente se realizaba, sobre todo, desde el Derecho privado, básicamente civil ${ }^{7}$.

de vecindad...) o bien obedecían a diferentes motivaciones e incluso a intereses económicos. Así lo indica Jordano Fraga, Jesús, La protección del derecho a un medio ambiente adecuado (Barcelona, Bosch, 1995), pp. 16 y 22.

${ }^{3}$ El Derecho se verá obligado a intervenir para solucionar conflictos derivados de la vida en los núcleos urbanos y uno de los más importantes será el relativo a los residuos por no existir canalizaciones ni lugares adecuados para su vertido. Véase Jordano FragA, Jesús, cit. (n. 2), p. 17 y Solidoro Maruotti, Laura, cit. (n. 1), pp. 79-81.

${ }^{4}$ Con carácter general, sobre la protección medioambiental en la Edad Moderna, sin limitarse al líquido elemento, véase Gómez Rojo, María Encarnación, Precedentes de protección medioambiental en el Derecho Histórico Español de la Edad Moderna, en ARANCIBIA MATTAR, Jaime - Martínez Estay, José Ignacio (coordinadores), La primacía de la persona. Estudios en homenaje al Profesor Eduardo Soto Kloss (Santiago de Chile, LegalPublishing, AbeledoPerrot, 2009), pp. 641-654. Cfr. UrTEAGA, Luis, Ideas medioambientales en el siglo XVIII (Madrid, Akal, 1997).

${ }^{5}$ No es la primera vez que examinamos cuestiones medioambientales o relacionadas con la contaminación de las aguas desde el punto de vista histórico-jurídico, aunque referidas a diferentes épocas o espacios geográficos. Véase Zambrana Moral, Patricia, La protección de las aguas frente a la contaminación y otros aspectos medioambientales en el Derecho romano y en el Derecho castellano medieval, en Revista de Derecho de la Pontificia Universidad Católica de Valparaiso, XXXVII (2o semestre, 2011), pp. 597-650; LA MISMA, Introducción a la Historia del Derecho medioambiental catalán: la salubridad de las aguas en las fuentes jurídicas de Barcelona y Tortosa en la Edad Media y Moderna, en Revista de Dret Històric Català, 11 (Barcelona, 2011, en prensa). Recogemos algunas de las ideas y conclusiones generales expuestas en estos artículos para introducir el presente trabajo, remitiéndonos a los mismos para un mayor desarrollo.

${ }^{6}$ Se pueden consultar distintos intentos de conceptualizar el medio ambiente, en MARTín Mateo, Ramón, cit. (n. 2), pp. 81-86; Fernández Gimeno, José Pascual - Gamborino Martínez, Gloria, en Reyes López, María José (coordinadora), Derecho ambiental español (Valencia, Tirant lo Blanch, 2001), pp. 29-32; o Llodrà Grimalt, Francesca, Lecciones de Derecho ambiental civil (Palma, Universitat de les Illes Balears, 2008), p. 17.

${ }^{7}$ Se trataba de amparar intereses y derechos particulares (sobre todo el derecho de propiedad), más que colectivos. Esto sucedía, especialmente en el Derecho romano y en el Derecho histórico español. No obstante, junto a los intereses privados aparecía en ocasiones el interés público y el supraindividual, aunque estaría limitado al ámbito higiénico sanitario o estético [Fernández Gimeno, José Pascual - Gamborino Martínez, Gloria, en Reyes López, María José (coordinador), cit. (n. 6), p. 12]. Cfr. Llodrà Grimalt, Francesca, cit. (n. 6), p. 21; Gómez Rojo, María Encarnación, cit. (n. 4), p. 642; Solidoro MARUOTTI, Laura, cit. (n. 1), pp. 130140; Jordano Fraga, Jesús, cit. (n. 2), pp. 18-19. 
Por el contrario, en la actualidad, la materia medioambiental tiene un marcado carácter interdisciplinario oscilando entre el Derecho público y el privado ${ }^{8}$.

Para efectuar un planteamiento de la evolución histórica, antes de entrar en materia, podemos afirmar que será en el Código de $\mathrm{Hammurabi}^{9}$ donde encontremos los primeros indicios de la protección ambiental aunque con escasa dedicación a las aguas ${ }^{10}$. No sucedería lo mismo con el Derecho romano que, dejando a un lado otros aspectos relacionados con el medio ambiente, prestaría gran atención a las aguas y a su tutela frente a la contaminación ${ }^{11}$. Pese a que no es nuestro objetivo el análisis de esta cuestión ${ }^{12}$, no podemos soslayar, por su

${ }^{8} \mathrm{~A}$ esta interdisciplinariedad, que se mueve entre el Derecho civil, penal, administrativo, internacional, comunitario, financiero o constitucional, nos hemos referido en otras ocasiones aportando una amplia bibliografía al respecto a la que nos remitimos. Véase ZAMBranA MORAL, Patricia, La protección de las aguas frente a la contaminación, cit. (n. 5), pp. 598-600; LA MISMA, Introducción a la Historia del Derecho medioambiental catalán, cit. (n. 5), notas 4-10.

${ }^{9} \mathrm{Cfr}$. The Oldest Code of Laws in the World: The Code of Laws Promulgated by Hammurabi, King of Babylon, B. C. 2285-2242 (trad. de Johns, C. H. W., Edinburgh, T. \& T. Clark, 1926; New Jersey, The Lawbook Exchange Ltd., 2000).

${ }^{10}$ Aquí se protegían los animales, prohibiéndose la sobreexplotación o la utilización indebida o negligente de los mismos. Sin embargo, estas normas iban dirigidas a defender la propiedad o a los animales como instrumentos de trabajo para la agricultura, más que a la especie o en sí mismos como elementos del medio ambiente. Cfr. Jaquenod Martínez, Silvia Susana, El Derecho ambiental y sus principios rectores (Madrid, Universidad Complutense, 1989), p. 71. De esta autora, consultar también Derecho ambiental (1 $1^{\mathrm{a}}$ edición, Madrid, Dykinson, 2002; 2a edición, 2004), en concreto, sobre aspectos históricos, pp. 181-191. En cuanto a las disposiciones del Código de Hammurabi relacionadas de algún modo con la materia ambiental, ver, por ejemplo, Código de Hammurabi, $\$ \$$ 245, 246, 247, 248, 254, 263, 264 y 267 (edición en francés en http://www.micheline.ca/doc--1730-hammourabi.htm y en inglés en http://public. wsu.edu/ dee/ MESO/CODE.HTM). Véase, asimismo, Éxodo 21, 37 y 22, 13-14. Mayor atención dedicamos a la regulación medioambiental en el Código de Hammurabi en ZaMBranA Moral, Patricia, La protección de las aguas frente a la contaminación, cit. (n. 5), pp. 601-603. Allí constatábamos que eran escasas las disposiciones de este cuerpo legal relacionadas con las aguas y ninguna con su contaminación. Se trataba de normas concernientes a los daños ocasionados por el agua en las tierras de labranza, próximas al Derecho penal, y eran solamente cuatro los preceptos dedicados a la irrigación de los campos (\$\$ 53-56).

${ }^{11}$ En general, sobre las aguas en el Derecho romano, podemos referir, aparte de los citados en otras ocasiones, el trabajo ya clásico de MAZZA, Alfredo, Dei diritti sulle acque. Manuale teorico pratico (Roma, Athenaeum, 1913), pp. 1-9 o los más recientes de Gerez KraEMER, Gabriel M., La distinción en España entre las aguas públicas y las aguas privadas desde el derecho romano hasta nuestros días, en Fernández de Buján, Antonio - Gerez Kraemer Gabriel - Malavé Osuna, Belén (coordinadores), Hacia un Derecho administrativo y Fiscal romano (Madrid, Dykinson, 2011), pp. 275-285. Ninguno de ellos aborda la cuestión medioambiental o la contaminación. Respecto a la protección jurídica de las aguas públicas, cfr. RuIZ, Salvador - AlbURQUERQUE, Juan Miguel, Algunas notas referentes a la experiencia administrativa romana de protección de los recursos naturales, en Fernández de Buján, Antonio - Gerez Kraemer Gabriel - Malavé OsunA, Belén (coordinadores), cit. (n. 11), pp. 409-426, en particular, pp. 422-426. Un par de referencias a la limpieza del alcantarillado para evitar malos olores y no perjudicar a los acueductos realiza Plocque, Alfred-Henri, Du régime legal des eaux servant a l'alimentation de la ville de Rome (tesis doctoral, Paris, Typographie de Henri Plon, Imprimeur de l'Empereur, 1868), pp. xlii y xlvi.

${ }^{12}$ Las disposiciones del Derecho romano relacionadas con el tema que nos ocupa fueron 
importancia, que la primera norma encaminada, de forma tal vez más directa, a preservar el medio ambiente se encontraba en el Digesto y tenía como finalidad, precisamente, la tutela de las aguas. Nos referimos a un texto de las sentencias de Paulo en el que aparecía la palabra "contaminaverit" y que se situaba en el título de extraordinariis criminibus ${ }^{13}$.

En el Derecho castellano medieval también hemos constatado la existencia de normas en las que se apreciaba una protección directa o tangencial de las aguas o dirigidas a evitar su contaminación, aunque el fin último fuese la defensa de otros intereses ${ }^{14}$. Lo mismo sucedía en el Derecho visigodo ${ }^{15}$, en el hispano-musulmán ${ }^{16}$ $y$ en el Derecho medieval y moderno de Barcelona y Tortosa ${ }^{17}$.

Continuando con esta línea de investigación pretendemos, como decíamos, analizar la tutela jurídica de las aguas como factor medioambiental en algunas disposiciones del Derecho castellano moderno, partiendo siempre de concepciones actuales, es decir, de lo que hoy se entiende por medio ambiente y por contami-

analizadas con detalle en ZamBrana Moral, Patricia, La protección de las aguas frente a la contaminación, cit. (n. 5), pp. 604-615. Algo apunta respecto a las servidumbres relacionadas con el agua: ARndTs RitTer von ARnesberg, Ludwig, Lehrbuch der Pandekten (7a edición, Stuttgart, 1872; 9a edición, Stuttgart, 1877, reimpresiòn anastática, Frankfurt am Main, 1983; 10a edición, Stuttgart, 1879, 14a edición, Stuttgart, 1889; traducción italiana de F. Serafini, 3 vols., Bologna, 1877-1880, en concreto, vol. I, 3a edición, Bologna, Tipi Fava e Garagnani, 1880), p. 392.

${ }^{13}$ D. 47,11,1,1 (Paul., 5 sent.). No se contenía una prohibición expresa, ni una sanción concreta, sino que se consideraba injuria contra las buenas costumbres todo acto dirigido a echar estiércol o manchar a alguien con cieno o lodo o ensuciar las aguas, cañerías y lagos y, en general, contaminar en perjuicio público.

${ }^{14}$ En la mayor parte de los fueros medievales había disposiciones encaminadas a regular el reparto, uso y disfrute del agua, básicamente para garantizar el riego, para evitar el despilfarro o que alguien la utilizase sin derecho (o la robase) perjudicando a terceros, para impedir las desviaciones del curso natural de las aguas, para reglamentar la construcción, funcionamiento y uso de molinos o para solucionar los problemas que surgían entre molinos situados a diferentes alturas. Más escasas eran las normas con proyección medioambiental vinculadas con la prohibición de ensuciar las aguas, con la limpieza, acondicionamiento y mantenimiento de canales, cauces y acequias o con la pesca e indirectamente con la tutela de la fauna. Una selección de estos fueros se recoge en Zambrana Moral, Patricia, La protección de las aguas frente a la contaminación, cit. (n. 5), pp. 623-636. Escasa atención prestaba el Fuero Real a la salubridad de las aguas aunque se prohibía de manera expresa modificar el curso natural de los ríos (Fuero Real, IV,6,6). En comparación a otros cuerpos legales, las Partidas dedicaban un mayor número de preceptos al agua y algunos sí que incidían en materia medioambiental, tal vez por influencia del Derecho romano. Véanse Partidas, III,28,3,4, 6 y 8; Partidas, III,31,4 y 5; Partidas, III,32, 13, 14, 15, 16 y 20 y, sobre todo, Partidas, III,32,7. Se comentaban estas disposiciones en Zambrana Moral, Patricia, La protección de las aguas frente a la contaminación, cit. (n. 5), pp. 639-645.

${ }^{15}$ Véanse Liber Iudiciorum, VIII,4,29 y Fuero Juzgo, VIII,4,29; Liber Iudiciorum, VIII,4,30 y Fuero Juzgo, VIII,4,30; Liber Iudiciorum, VIII,4,31 y Fuero Juzgo, VIII,4,31; Liber Indiciorum, VII,2,12 y Fuero Juzgo, VII,2,12.

${ }^{16}$ Sobre el derecho hispanomusulmán, véase lo que dijimos en Zambrana Moral, Patricia, La protección de las aguas frente a la contaminación, cit. (n. 5), pp. 616-621.

${ }^{17}$ Véase Zambrana Moral, Patricia, Introducción a la Historia del Derecho medioambiental catalán, cit. (n. 5). 
nación ${ }^{18}$. No son muchos los que han examinado esta cuestión ${ }^{19}$ y los que lo han hecho la han planteado a modo de introducción de un estudio más amplio del Derecho ambiental ${ }^{20}$. En cualquier caso, el análisis histórico de las aguas se ha realizado normalmente, con independencia del ámbito geográfico, desde el punto de vista administrativo y económico, sobre todo, en relación a su aprovechamiento, en especial, para la agricultura, limitándose al riego $^{21} \mathrm{o}$ a acequias concretas ${ }^{22}$, sin atender, salvo excepciones, a su salubridad.

${ }^{18}$ Un concepto de contaminación se contiene en el artículo 93 del Real Decreto Legislativo No 1/2001, de 20 de julio, por el que se aprueba el texto refundido de la Ley de Aguas, en su redacción dada por la Ley No 62/2003, de 30 de diciembre.

${ }^{19}$ Tal vez no sea extraño si tenemos en cuenta que la propia legislación histórica ha dedicado escasa atención a las aguas en sí mismas.

${ }^{20}$ Ejemplos de esta afirmación lo encontramos en los trabajos de Jordano FraGA, Jesús, cit. (n. 2), pp. 16-31 (Edad moderna en pp. 25-31); JAQUENOD MARTínez, Silvia Susana, cit. (n. 10), pp. 69-92, en particular, pp. 73-90; Fernández Gimeno, José Pascual - Gamborino Martínez, Gloria, en Reyes López, María José (coordinadora), cit. (n. 6), pp. 13-14; Vergara Blanco, Alejandro, Derecho de Aguas (Editorial Jurídica de Chile, Santiago de Chile, 1998), I, pp. 29-90; EL MISMO, Contribución a la historia del derecho de aguas, II: Fuentes y principios del derecho de aguas español medieval y moderno, en Revista de Derecho de Minas y Aguas, 2 (1991), pp. 137-161 Todos ellos analizan, en las páginas indicadas, la evolución histórica del Derecho ambiental, de manera escueta y genérica. Centrada en el Derecho catalán, aunque al margen del Derecho ambiental (al menos directamente), sí que resulta de obligada consulta la completa y documentada obra de TEIRA VILAR, Francisco Javier, El régimen jurídico de aguas en el Llano de Lérida (siglos XII a XVIII), con "Prólogo" de FonT I RIUs, Josep M. (Barcelona, Universidad de Barcelona, Facultad de Derecho, Cátedra de Historia del Derecho Español, 1977). Aquí examina con detalle el régimen de las aguas en la huerta ilerdense. Se ocupa de la titularidad de los derechos, de la administración (régimen y organización), de la eficiente gestión del servicio de suministro (construcción y mantenimiento de acequias, aprovechamientos y policía) y de aspectos procesales y financieros.

${ }^{21} \mathrm{Cfr}$. Riu, Manuel, El agua y su aprovechamiento en las ciudades y villas catalanas medievales, en El món urbà a la Corona d'Aragó del 1137 als decrets de nova planta: XVII Congrés d'Història de la Corona d'Aragó, Barcelona-Lleida, 7-12 setembre del 2000 (Actes, Barcelona, Edicións Universitat de Barcelona, 2003), I, pp. 539-555 y 548 y, en cuanto al riego de las huertas, la construcción de nuevas acequias y la reorganización de los regadíos, pp. 548-551. Sobre el aprovechamiento del agua para el riego (origen del derecho al uso, regulación y prestaciones para los agricultores), véase: TEIRA VILAR, Francisco Javier, cit. (n. 20), pp. 245-294 y 320-323. Véase también: Cuvillier, Jean Pierre, L’irrigation dans la Catalogne médiévale et moderne, en Mélanges de la Casa de Velázquez, 20 (1984), pp. 145-187; AyMARD, Maurice, Irrigations du Midi de l'Espagne: études sur les grands travaux hydrauliques et le régime administratif des arrosages de cette contrée (Paris, 1964); Garrabou Segura, Ramón - Naredo Pérez, José Manuel (editores), El agua en los sistemas agrarios: una perspectiva histórica (Madrid, Fundación Argentaria, Visor Distribuciones, 1999); Llauradó, A., Tratado de aguas y riegos (Madrid, Imprenta de Moreno y Rojas, 1884), 2 volúmenes; BARCELó, Miquel, (coordinador), The Design of Irrigation Systems in al-Andalus (Barcelona, Universitat Autònoma de Barcelona, 1998); GLICK, T. F., Regadio y sociedad en la Valencia medieval (Valencia, 1988); y LÓPEZ GÓMEZ, A., Estudios sobre los regadios valencianos (Valencia, Universitat de València, 1989).

${ }^{22}$ Véase TAsso YzQuierdo, Rafael, Algunos datos sobre la historia, descripción y actuación de la Acequia Real del Júcar (Valencia, 1945; 2a edición, 1964); GuAl CAMARENA, Miguel, Estudio histórico-geográfico sobre la Acequia Real del Júcar (Valencia, Instituto de Geografía, Institución Alfonso El Magnánimo, Diputación Provincial de Valencia, Acequia Real del Júcar, 1979); Belando, Juan, Estudio sobre el río Segura y la huerta de Murcia (Murcia, 1878); Delgado, 


\section{ORDENANZAS LOCALES}

Entrando ya en el Derecho castellano de la Edad Moderna, la mayoría de las disposiciones que hemos localizado se ocupan del problema del riego, de los vertidos en el mar o en los ríos, de la prohibición de cerrar éstos o de pescar en determinadas épocas del año o de forma que la especie se pueda ver afectada ${ }^{23}$. Asimismo, se advierte una preocupación, cada vez mayor, por la limpieza de fuentes, pozos y acequias ${ }^{24}$, por el alcantarillado y la canalización de las aguas fecales y por delimitar las competencias de las autoridades encargadas del control de la higiene de las ciudades ${ }^{25}$.

En esta época, normalmente, las cuestiones relativas a las aguas, a su cuidado, mantenimiento, limpieza y protección frente a la contaminación se solían recoger en disposiciones de carácter local, sobre todo en ordenanzas municipales ${ }^{26}$. Eran

Pedro, La real acequia del Jarama (Madrid, Ministerio de Obras Públicas, Transportes y Medio Ambiente, Centro de Publicaciones, 1995), 2 volúmenes.

${ }^{23}$ Precisa Jesús Jordano Fraga que "la creciente presión del hombre sobre la fauna, como recurso natural, hizo necesaria la intervención del Derecho para evitar que las actividades de la caza y la pesca acabaran por producir una disminución relevante o la extinción de este recurso". Por este motivo, en la época que nos ocupa, se promulgaron muchas normas "dirigidas a limitar la caza y la pesca, cuantitativamente, mediante la fijación de vedas, y, cualitativamente, mediante la restricción de modos y medios utilizables" [Jordano FraGa, Jesús, cit. (n. 2), pp. 25-26].

${ }^{24} \mathrm{La}$ obligación de limpiar las acequias estaba ya presente en el Derecho romano, donde se prohibía que se tratase de impedir violentamente el saneamiento y reparación de acequias, canales cubiertos, o presas por las que discurría el agua [D. 43,21,1 pr. (Ulp., 70 ed.)], haciéndose extensiva dicha prohibición a las fuentes [D. 43,22,1,6,7 y 8 (Ulp., $70 \mathrm{ed}$.)], pozos, lagos y piscinas [D. 43,22,1,10 (Ulp., 70 ed.)]. Esta obligación sería una constante en los fueros medievales castellanos. Se solía regular de forma minuciosa por su importancia para la viabilidad de las acequias, más que para garantizar la salubridad del agua, aunque este objetivo se conseguía indirectamente. Cfr. Fuero de Molina de Aragón, 30; Fuero de Béjar, 196; Fuero de Cuenca, VIII, 12; Fuero de Andújar, 150 o Fuero de Soria, \$265 [Zambrana Moral, Patricia, La protección de las aguas frente a la contaminación, cit. (n. 5), pp. 624, 628, 633 y 634]. Precisa Teira Vilar que el conjunto normativo de las diversas zonas peninsulares no ofrece diferencias de principio en la regulación de la "monda" o "escombre" de las acequias, lo que no impide que se den "variantes comarcales de índole secundaria" [TeIRA VILAR, Francisco Javier, cit. (n. 20), p. 185 y pp. 226-242]. Nada dice Teira sobre la posible contaminación que ocasionaría la falta de limpieza. Tan solo habla de la necesidad de vigilar las condiciones sanitarias del agua cuando ésta se destinaba al consumo humano y de salvaguardar su "potabilidad" prohibiendo "echar residuos y productos perniciosos a las acequias" y a las fuentes de la ciudad (pp. $304 \mathrm{y}$ 326). Ruiz-Funes García aludía al "problema higiénico" y al riesgo de inundación para justificar la necesidad de limpiar las acequias murcianas [RUIZ-Funes GARCíA, Mariano, Derecho consuetudinario y economía popular de la provincia de Murcia, con "Prólogo" de CERDÁ RUIZ-FunES, Joaquín (Murcia, Academia Alfonso X el Sabio, reimp. 1983), p. 141].

${ }^{25}$ No podemos obviar que el urbanismo de la Edad Moderna tiene en cuenta la red de alcantarillado de las ciudades y que, en concreto, en Madrid, se debe, en gran parte, a Carlos III su configuración.

${ }^{26}$ Véase Ladero Quesada, Miguel Ángel - GalÁN ParRa, Isabel, Las ordenanzas locales en la Corona de Castilla como fuente histórica y tema de investigación (siglos XIII al XVIII), en Anales de la Universidad de Alicante. Historia Medieval, 1 (1982), pp. 221-243. Por su parte, Francisco Javier Teira Vilar apuntaba al carácter básicamente local de las antiguas regulaciones jurídicas en la materia [TeIRA VILAR, Francisco Javier, cit. (n. 20), pp. 17-18]. 
estas ordenanzas las que se ocupaban de velar por aspectos relacionados con el medio ambiente desde el punto de vista higiénico-sanitario o de salud pública. A continuación, recogemos algunas de ellas, por poner varios ejemplos.

Especial interés ponían las "Ordenanzas municipales del Castillo de Garcimuñoz" de 1497 en la limpieza del "pozo Duz", tarea que correspondía al arrendador una vez al año, siempre que lo arrendase. Si incumplía con este cometido, el Concejo podía llevar a cabo la desinfección a su costa. A nadie le estaba permitido sacar los cántaros o sogas que cayesen en el pozo hasta el momento en que se llevase a cabo dicha limpieza, bajo multa de treinta maravedís para el arrendador. Con el fin de garantizar el saneamiento, se prohibía lavar con agua del pozo, castigándose esta acción con una pena pecuniaria de sesenta maravedís $^{27}$. Del mismo modo, en estas ordenanzas se prestaba atención al cuidado de las madres y acequias, estableciéndose que cuando en ellas había abrevaderos, los que las utilizasen estaban obligados a limpiarlas bajo pena de diez maravedís por cada rebaño o cabaña que abrevare, de forma que la dejase "limpia e corriente". También se limitaba la entrada o apacentamiento de "bestias" en las acequias con una serie de sanciones económicas; en concreto, treinta maravedís por cada bestia que estuviese apacentando, una parte para el demandante, otra para el juez, ya fuese alcalde o regidor, y la última para la villa. Si el que entraba era "ganado menudo", la multa sería de doscientos maravedís, además de la obligación de limpiar por parte del dueño del ganado. Sin embargo, cuando no superaba las cincuenta reses se imponía la sanción de un maravedí por cada res y si excedía de cincuenta, doscientos maravedís con la referida limpieza de las acequias, en ambos casos, repartiéndose las cantidades del modo antes señalado ${ }^{28}$.

En las "Ordenanzas de la ciudad de Murcia" de 1536 se controlaban los vertidos de residuos en la ciudad, entre los que se incluían despojos de animales, agua sucia, basura y cualquier clase de inmundicia o suciedad. El control de la limpieza urbana correspondía a los ejecutores y al almotacén. En la época medieval, era frecuente que los vecinos tirasen agua sucia, incluidas las fecales, desde sus casas a la calle, debido a la falta de un sistema de alcantarillado o pozos ciegos, lo que provocaba malos olores y un elevado nivel de contaminación ambiental ${ }^{29}$. Se prohibía de manera expresa a los turdidores arrojar el agua que acumulaban en las pilas donde mojaban los paños porque ocasionaban barrizales en las calles. La pena era de cien maravedís, un tercio para la ciudad, otro para el denunciante o almotacén y otro para la justicia ${ }^{30}$. No obstante, se observa poca preocupación ambiental cuando se ordenaba a los triperos que echasen al río, debajo de la torre

\footnotetext{
27 “Ordenanzas Municipales del Castillo de Garcimuñoz" de 1497, título XXXIV [edición, introducción y apéndices de Abellán Pérez, Juan y García Guzmán, Ma del Mar, (Departamento de Historia medieval, Servicio de Publicaciones, Universidad de Cádiz, Cádiz, 1985), pp. 120-122].

${ }^{28}$ Ibíd., pp. 124-125].

${ }^{29}$ Ordenanzas de la ciudad de Murcia (1536) (edición y estudio de González Arce, José Damián, Universidad de Murcia, Servicio de Publicaciones, Murcia, 2000), pp. 50-51.

${ }^{30}$ Ibíd., título XXI, p. 86.
} 
de Caramajud, las tripas, cuernos y restos de animales para evitar hedores en la ciudad, ya que no había otro vertedero ${ }^{31}$.

Un lugar relevante en el tema que nos ocupa tendrían las "Ordenanzas de Granada” de 1552 que mostraron una gran preocupación por la limpieza e higiene de las ciudades ${ }^{32}$, sin obviar otras disposiciones sobre la tala de árboles ${ }^{33}$ y quema de rastrojos ${ }^{34}$. En materia de aguas, se obligaba a la limpieza de las acequias por parte del propietario de las heredades donde se encontrasen ${ }^{35}$. Se prohibía la pesca de truchas y peces, cortando o enturbiando los ríos o utilizando explosivo o veneno. Se especificaba la forma en que se debía pescar y se sancionaba el incumplimiento con mil maravedís y la pérdida de los aparejos a repartir, por tercios, entre el guarda o acusador, los propios de la ciudad y los jueces que dictaron la sentencia. Con el fin de proteger la especie, no se permitía la pesca de trucha en diciembre, enero y febrero y sólo podía hacerse con caña ${ }^{36}$.

${ }^{31}$ Ibíd., ordenanza VI, p. 86. No obstante, en las "Ordenanzas de Murcia" de 1695, que serían confirmadas por Carlos II se prohibía echar inmundicias al río [Cfr. JAQUENOD MARTÍNEZ, Silvia Susana, cit. (n. 10), p. 89]. Anteriormente, en las "Ordenanzas de Loja" de 1503 se mostraba una clara preocupación por el cuidado de los recursos hidráulicos.

${ }^{32}$ Por ejemplo, hay un título específico que recoge las "Ordenanzas del Matadero", con un apartado Sobre las tripas, donde se indicaba el lugar exacto al que debían llevarse los restos, sancionándose con doscientos maravedís si se dejaban en el mismo matadero y con cien si se tiraban a otro sitio, además de la limpieza a costa del que incumplía estas obligaciones. Asimismo, se contemplaba la necesidad de limpiar la sangre y cualquier suciedad del matadero cada dos días, bajo pena de dos reales si no se hacía ("Ordenanzas de Granada" de 1552, fols. xxxvi r-xxxvi v y XLv). Hemos seguido la edición facsímil de la primera colección impresa de estas ordenanzas, con introducción de López Nevot, José Antonio (Granada 2000). Véase también la disposición, Para que no anden puercos del Alcalde en el matadero, dentro de la misma ordenanza, donde se mostraba preocupación por la limpieza de los mataderos (fol. xxxvi v); así como las "Ordenanzas de carniceros" en las que se exigía que estos hombres llevasen delantales y que el lugar donde se cortaba la carne estuviese limpio (fols. xxxvvii v-xxxviii r). Igualmente, en la Ordenanza donde se ha de echar la tierra y el cascajo se observaba un interés por la higiene y por los efectos perjudiciales de la acumulación de basuras, ya que se incidía en la prohibición de echar cascajo, estiércol o basura junto al muro de la ciudad, ni por dentro ni por fuera de la misma, bajo pena de cincuenta maravedís, insistiéndose en que el estiércol no se debía arrojar en lugar distinto del destinado al efecto (el hoyo que estaba delante de la puerta de Elvira) con una sanción de doce maravedís, ya que se podían ocasionar muchos daños (fol. ccxlv v ). Cfr. JaQUenod Martínez, Silvia Susana, cit. (n. 10), pp. 77-78.

33 "Ordenanzas de Granada" de 1552, Ordenanzas sobre los balates y caminos y acequias, fols. liii r-lvi r y, de manera más específica, Ordenanzas sobre las talas y cortes de montes, con alguna referencia a los incendios y a la caza, fols. lvi r-lxiv v. Sobre la caza, véanse Ordenanzas del tiempo que ha de estar vedada la caza, fols. cv r-cvii r.

${ }^{34}$ Se prohibía, sin licencia, hasta finales de agosto ("Ordenanzas de Granada" de 1552, Ordenanzas del quemar de los rastrojos en esta ciudad y su tierra, fols. ci v-cii v). Tampoco se permitía hacer carbón o ceniza en los términos de la ciudad y alrededores (seis leguas), sin licencia, ni con árboles frutales, ni con encina ("Ordenanzas de Granada" de 1552, Ordenanzas de cómo se ha de hacer el carbon y ceniza, fols. cviii r-cix r).

35 "Ordenanzas de Granada" de 1552, Ordenanzas del orden de plantar de los arboles, fols. ciii v-civ v. Aquí se indicaba también cómo se debía repartir el agua de las fuentes y de los ríos para permitir el riego.

${ }^{36}$ Ibíd., Ordenanzas de pescadores de truchas y peces y los precios porque se han de vender, fol. cvii r y fol. cccxix r. 
Dentro de las “Ordenanzas de Granada”, el mayor interés en esta sede lo revisten, sin duda, las "Ordenanzas de las aguas" ${ }^{37}$ que contienen un elevado número de disposiciones cuyo fin era garantizar la limpieza, la conservación y la buena administración de las aguas de la ciudad de Granada y regular los oficios relacionados con las mismas ${ }^{38}$. Se incluyen las "Ordenanzas del acequiero de las acequias del río Darro en el campo", que obligaban al acequiero ${ }^{39}$ que estuviese a cargo de dicho río a tener limpias las acequias y lugares por donde pasaba el agua de "palos, hojas y otras inmundicias" que pudiese arrastrar aquélla, bajo pena de quinientos maravedís más la reparación de los daños que se ocasionasen ${ }^{40}$. Hay otras normas más específicas, se trata de las Ordenanzas del limpiar de las dichas acequias, donde se exigía el saneamiento de las mismas dos veces al año "muy bien limpias", una en marzo y otra en septiembre, concretando quiénes debían llevar a cabo dichas tareas (dependiendo de dónde se encontrase la acequia y de quién la utilizase), en primer lugar, el encargado de las obras hidráulicas en la ciudad, seguido de los vecinos que tuvieran huertas que regasen con el agua de las referidas acequias. La sanción en caso de incumplimiento era de quinientos maravedís y siempre se tenían que respetar los derechos de terceros. La limpieza se debía hacer a la vista y con el parecer del administrador de las aguas quien podía requerir a los interesados a que las limpiasen más veces, si era necesario ${ }^{41}$. Especial preocupación se mostraba por el saneamiento de las acequias dentro de la ciudad que se haría cada mañana y siempre que fuese preciso y, sobre todo, en

${ }^{37}$ En 1527, Carlos I ordenó la reforma de las “Ordenanzas de las aguas de Granada” y, por Real Cédula de 29 de marzo de 1535, se encargó dicha reforma al licenciado Briceño, oidor de la Audiencia. Éste, junto al corregidor, Hernán Arias de Saavedra y el alcalde, Francisco de Padilla hicieron unas "Ordenanzas para el guiamiento, limpieza y conservación de las aguas de la dicha Ciudad de Granada [...]”. Tras varias enmiendas y modificaciones por las que se eliminaban algunos aspectos que se consideraban perjudiciales para la ciudad, fueron aprobadas ("Ordenanzas de Granada” de 1552, Ordenanzas de las aguas, fols. cclxv r-cclxv v). Estas ordenanzas fueron confirmadas por Carlos I en 1538 y recopiladas en 1552 (fol. cclxxxiii r).

${ }^{38}$ Tras ocuparse de describir las técnicas de regadío utilizadas por los musulmanes (presa, noria y pozo horizontal o "qanat"), su organización, administración, regulación y pervivencia en época cristina, María Teresa de Diego Velasco realiza un estudio de estas ordenanzas [DE DiEGO Velasco, María Teresa, Las Ordenanzas de las Aguas de Granada, en En la España Medieval, 4 (1984), pp. 249-275].

${ }^{39} \mathrm{El}$ acequiero era el encargado de limpiar y mantener en buen estado de conservación las acequias y además, repartía el agua y controlaba los turnos de riego y custodiaba las instalaciones acuíferas (edificios de aguas). Debía dar cuenta de todo lo relativo a acequias, ramales y edificios de aguas, al administrador de las aguas. Según Riu, el acequiero era el responsable de la limpieza y conservación en perfecto uso de las acequias [Riu, Manuel, cit. (n. 21), p. 549].

40 "Ordenanzas de Granada" de 1552, fols. cclxvi r-cclxvi v. La división del agua en canales y acequias era una de las técnicas de regadío más utilizadas en la España musulmana y el sistema seguido en Granada (donde tenía gran importancia este tipo de cultivo), según se desprende de la terminología de sus ordenanzas. Así, el río Darro se dividía en cuatro acequias y el Genil en tres, y cada acequia se dividía, a su vez, en ramales que se extendían por toda la ciudad para distribuirse por las casas, huertas, fuentes, etc. Lo indica, al analizar esta técnica, DE DIEGO Velasco, María Teresa, cit. (n. 39), pp. 251 y 256. Con más detalle, examina cada una de las acequias, con base en el texto de las ordenanzas, en pp. 263-264.

41 "Ordenanzas de Granada” de 1552, fols. cclxvi v-cclxvii r. 
época de caída de las hojas. Lo mismo se establecía en relación a las albercas y otros lugares por donde pasaba el agua, respecto a hojas, palos, arena, cieno, etc. Había que procurar que el agua estuviese bien conducida y no se desperdiciara por las calles, y que la ciudad fuese abastecida con agua clara, adoptándose las medidas oportunas si las aguas venían turbias como consecuencia de alguna crecida. De nuevo, se imponían penas pecuniarias, entre doscientos y quinientos maravedís, para sancionar el incumplimiento de estas obligaciones, junto con la limpieza a costa del responsable ${ }^{42}$. En otra ordenanza, se disponía que en las casas del Realejo en las que se labrase barro, una persona debía limpiar la alberca cuando fuera menester, castigándose, en caso contrario, con cincuenta maravedís ${ }^{43}$.

Sobre la limpieza, guarda y conservación de las aguas, hay unas normas generales, algunas de ellas con evidente contenido medioambiental al ir claramente dirigidas a evitar la contaminación. Se trata de las Ordenanzas de todas las cosas tocantes a las aguas, así para la limpieza, guarda y conservación dellas como de todo lo demás. En ellas, se intentaba controlar el uso del agua a través de libros y registros $^{44}$. Además, se sancionaba con mil maravedís a todo aquél que agrandase o mandase agrandar "el tomadero" de agua de su vivienda, elevándose la multa a cinco mil maravedís, si se trataba de un oficial. Si no se podía averiguar quién lo hizo o quién efectuó el encargo, el dueño de la casa debía pagar mil maravedís además de devolver "el tomadero" a su estado original ${ }^{45}$. Se exigía pedir licencia al corregidor, a uno de los alcaldes del agua y al administrador para renovar o cambiar el cauchil y para sustituir el tomadero de las casas, bajo pena de dos mil maravedís para el propietario y quinientos para el oficial que lo hiciera sin autorización ${ }^{46}$. No se podía abrir caño ni acequia en la calle sin licencia del corregidor y del administrador, castigándose con dos mil maravedís al que lo ordenase y quinientos para el que lo hiciese, salvo que fuese dentro de un domicilio parti-

${ }^{42}$ Ibíd., Ordenanzas de los acequieros de las dichas acequias de dentro de la ciudad, fols. cclxvii r-cclxviii r. Hay también ordenanzas relativas a acequias concretas y otras en las que se disponía cómo y cuándo se debía utilizar el agua del Darro y del Genil para el riego y cómo se tenían que regar algunas huertas del Darro (fols. cclxviii r-cclxx r). Especialmente extensas son las "Ordenanzas de la acequia de Alfacar" (una de las más importantes) donde se regulaba el uso y reparto del agua y se insistía en su limpieza y en la de los aljibes y albercas (cfr. fols. cclxx r-cclxxii v). Hay otras dirigidas, en concreto, a la limpieza de la acequia de Axares en la calle, desde el Monasterio de Nuestra Señora de la Victoria, hasta la Iglesia de San Juan de los Reyes, que había de hacerse por los arrendadores de la acequia de "Darrillo el Sucio", tal y como era costumbre, una vez al año y cuantas veces considerase oportuno el administrador, y hasta llegar al suelo, debiendo llevarse fuera de la ciudad todo lo que de ella se sacase, en un plazo de tres días, bajo pena de mil maravedís (fol. cclxxiii r). En cuanto a los aljibes y aljiberos, Véase fol. cclxix r. y lo que dice, al respecto de los aljibes y fuentes que abastecían de agua a Granada, DE Diego Velasco, María Teresa, cit. (n. 39), pp. 267-268.

${ }^{43}$ Ibíd., Ordenanza sobre el limpiar la alberca del Realejo, fol. cclxx r.

${ }^{44}$ Ibíd., Ordenanzas de todas las cosas tocantes a las aguas, así para la limpieza, guarda y conservación dellas como de todo lo demás, fols. cclxxvii r-cclxxvii v.

${ }^{45}$ Ibíd., Ordenanzas de todas las cosas tocantes a las aguas, así para la limpieza, guarda y conservación dellas como de todo lo demás, fols. cclxxiii r-cclxxiii v.

${ }^{46}$ Ibíd., Ordenanzas de todas las cosas tocantes a las aguas, así para la limpieza, guarda y conservación dellas como de todo lo demás, fol. cclxxiii v. 
cular y, aun así, había que pedir permiso. La misma licencia se exigía, junto con la de uno de los alcaldes del agua, parar cortar el agua de las acequias o caños impidiendo que el agua limpia entrase en la ciudad, siendo, en este caso, la pena de mil maravedís y el que desviaba o tomaba el agua debía pagar una multa de tres mil maravedís ${ }^{47}$. El fin era evitar, en general, el fraude en la utilización del líquido elemento causando graves perjuicios a los demás. Las penas aumentaban cuando para este uso ilegal se forzaban cerraduras o candados, debiendo, además, repararse éstos ${ }^{48}$. Asimismo, se protegían las acequias y cauchiles de cualquier daño intencionado con una pena de tres mil maravedís o treinta días de prisión en caso de insolvencia y, si el delito lo cometía un esclavo por orden de su amo, recibiría cincuenta azotes públicamente y estaría encarcelado hasta que el amo pagase todos los perjuicios ocasionados ${ }^{49}$.

Por lo que respecta al agua en sí misma, hay preceptos destinados, de manera específica, a garantizar su limpieza y, por ende, a impedir su contaminación, por ejemplo, la que se podía ocasionar al arrojar a las acequias, canales o azacayas un animal muerto (perro, gato o gallina) o cualquier suciedad o al lavar en ellos un bacín ${ }^{50}$ u otra cosa similar, hasta el punto de que al que lo hiciera se le impondría una pena pecuniaria de tres mil maravedís y una privativa de libertad de veinte días de cárcel y, subsidiariamente, cincuenta días de prisión, si era insolvente ${ }^{51}$. De forma expresa, se prohibía lavar paños y lienzos o remojar telas en cauchil, aljibes o acequias dentro o fuera de la ciudad, cuando llevasen agua a ésta, bajo sanción de dos mil maravedís. En las proximidades de los edificios hidráulicos no estaba permitido lavar nada en artesa ni lebrillo, ni tomar agua de los mismos, sancionándose el incumplimiento con una pena de quinientos maravedís. Si se trataba de un esclavo y su amo no quería pagar, recibiría veinte azotes en la cárcel ${ }^{52}$. Los vecinos no podían vaciar sus letrinas en las acequias. También se prohibía meter caldera, vasija u otra cosa sucia en aljibe, cauchil, acequia o pilar de agua clara. En este caso, la sanción era de veinte maravedís y, de forma subsidiaria, en caso de insolvencia, veinte días en prisión y, si se echaban en remojo suelas o cueros en acequia, pilar, cauchil, aljibe o azacaya, quinientos maravedís y, subsidiariamente, quince días de cárcel ${ }^{53}$. La misma sanción pecuniaria pero incrementando los días de prisión en veinte, si no podía hacer frente al pago, se impondría al que lavase pescado " $u$ otra cosa semejante" en el agua limpia. Si lo que se lavaban eran

${ }^{47}$ Ibíd., Ordenanzas de todas las cosas tocantes a las aguas, asi para la limpieza, guarda y conservación dellas como de todo lo demás, fols. cclxxiii v-cclxxiv r.

${ }^{48}$ Ibíd., Ordenanzas de todas las cosas tocantes a las aguas, así para la limpieza, guarda y conservación dellas como de todo lo demás, fols. cclxxiv r-cclxxiv v.

${ }^{49}$ Ibíd., Ordenanzas de todas las cosas tocantes a las aguas, asi para la limpieza, guarda y conservación dellas como de todo lo demás, fol. cclxxv r.

${ }^{50}$ Debe referirse al recipiente que contenía excrementos humanos.

51 "Ordenanzas de Granada” de 1552, Ordenanzas de todas las cosas tocantes a las aguas, así para la limpieza, guarda y conservación dellas como de todo lo demás, fols. cclxxv r-cclxxv v.

52 Ibíd., Ordenanzas de todas las cosas tocantes a las aguas, asi para la limpieza, guarda y conservación dellas como de todo lo demás, fol. cclxxv v.

${ }^{53}$ Ibíd., Ordenanzas de todas las cosas tocantes a las aguas, asi para la limpieza, guarda y conservación dellas como de todo lo demás, fols. cclxxv v-cclxxvi r. 
hortalizas, la primera vez se castigaba con doscientos maravedís, la segunda con el doble, y la tercera con el triple y si el autor del hecho no tenía con qué pagar sufría diez días de privación de libertad ${ }^{54}$. Tampoco se podía introducir en el agua limpia esparto o sogas, penándose con doscientos maravedís 55 . Los "muchachos" que causaban daños en los caños de agua, pilares, azacayas o aljibes o en cualquier otra instalación similar eran conducidos a prisión pública por un día ${ }^{56}$. Si alguien era sorprendido in fraganti infringiendo lo dispuesto en estas ordenanzas sería detenido y llevado a la cárcel de la ciudad para que allí le fuese ejecutada la correspondiente pena, sobre su persona y sobre sus bienes ${ }^{57}$.

En cuanto a las aguas residuales, había una acequia concreta, dividida en dos ramales ("Darrillo el sucio" o "Darrillo el turbio"), encargada de conducir dichas aguas y los desechos fuera de la ciudad ${ }^{58}$, aparte de otras instalaciones encargadas de recogerlas. En las "Ordenanzas de las aguas sucias”, se establecía que cualquier edificio relacionado con las mismas ("edificios de aguas sucias") debía tener las correspondientes licencias administrativas y la construcción sería en la forma señalada, de modo que no se mezclasen las aguas limpias con las sucias y éstas no causasen daños a aquéllas o a las calles de la ciudad ${ }^{59}$. Nadie podía quitar el agua de las cloacas o caños de aguas sucias salvo necesidad urgente y, si lo hacía, se le imponía una multa de mil maravedís. Lo mismo se establecía para el que retiraba alguna piedra de la acequia del Darrillo sin licencia ${ }^{60}$. Se prohibía lavar trapos o cualquier cosa en la presa y caz del molino que estaban en Plaza Nueva por los perjuicios que se podían ocasionar a la referida presa. La pena por cada vez que se hiciese era de cien maravedís. Cuando en la limpieza de las acequias se extraía cieno u otra cosa, se tenía que llevar fuera de la ciudad en un plazo de tres

${ }^{54}$ Ibíd., Ordenanzas de todas las cosas tocantes a las aguas, asi para la limpieza, guarda y conservación dellas como de todo lo demás, fol. cclxxvi r.

${ }^{55}$ Ibíd., Ordenanzas de todas las cosas tocantes a las aguas, asi para la limpieza, guarda y conservación dellas como de todo lo demás, fol. cclxxvi r.

${ }^{56}$ Ibíd., Ordenanzas de todas las cosas tocantes a las aguas, asi para la limpieza, guarda y conservación dellas como de todo lo demás, fols. cclxxvi r-cclxxvi v. En torno al control del uso del agua, Véase fols. cclxxvi v-cclxxvii v.

${ }^{57}$ Ibíd., Ordenanzas de todas las cosas tocantes a las aguas, así para la limpieza, guarda y conservación dellas como de todo lo demás, fol. cclxxvii v. Se dedican expresamente unas ordenanzas al administrador de las aguas, sus oficiales y las competencias de cada uno, así como a los Alcaldes y Jueces de Aguas (fols. cclxxviii v-cclxxxiii r). En Granada, había un Juzgado Privilegiado de las aguas creado en 1501. En líneas generales, al administrador de las aguas le correspondía nombrar a los acequieros y a otros subordinados, reparar las acequias y velar por su limpieza y mantenimiento. Sobre los orígenes de este cargo, salario, nombramiento de oficiales, funciones en materia de regulación y uso del riego, obras, reparaciones y su intervención en las irregularidades en el uso de las aguas domésticas, véase De Diego Velasco, María Teresa, cit. (n. 39), pp. 258-261.

${ }^{58}$ Se alude a esta acequia en "Ordenanzas de Granada" de 1552, Ordenanzas de los acequieros de las dichas acequias de dentro de la ciudad, fols. cclxvii r-cclxviii r. Hay que tener en cuenta que las agua residuales también se utilizaban para el riego.

59 “Ordenanzas de Granada” de 1552, Ordenanzas de las aguas sucias, fols. cclxxvii v. El incumplimiento se castigaba con multa de cinco mil maravedís para el que encargaba la obra y mil para el oficial que la ejecutase, además de ser derribada a su costa.

${ }^{60}$ Ibíd., Ordenanzas de las aguas sucias, fols. cclxxvii v-cclxxviii r. 
días y si alguien lo dejaba en la calle se sancionaba con trescientos maravedís y la obligación de retirarlo a su costa. Para evitar que las carretas provocasen daños en las acequias, caños y cloacas, con las consiguientes repercusiones medioambientales, aquéllas debían contar, para entrar en la ciudad (salvo alguna excepción), con una licencia del corregidor o del administrador de las aguas; caso contrario, se sancionaría con mil maravedís y la pérdida de la carreta ${ }^{61}$. Con el objetivo de garantizar la higiene se estableció que las letrinas estuviesen apartadas de las cloacas y se reguló el tamaño de los agujeros de la rejilla de hierro que tapaba el caño que desembocaba en dichas alcantarillas ${ }^{62}$.

Igualmente relacionadas con la tutela medioambiental, se encontraban las “Ordenanzas del Común de la Villa de Segura y su Tierra” de $1580^{63}$. Su fin principal era proteger y administrar los montes de Segura, de ahí que la mayoría de sus disposiciones incidiesen en materia forestal. Fue la normativa utilizada en la Sierra de Segura para el mantenimiento, conservación y aprovechamiento de todos sus recursos ${ }^{64}$. Respecto al agua, se intentaba garantizar su limpieza para el uso humano evitando que abrevasen puercos o se lavasen cosas sucias en las fuentes y sus nacimientos, bajo pena de seiscientos maravedís ${ }^{65}$. Se recogía el derecho de los habitantes de la Sierra a cazar y a pescar para cubrir sus necesidades, pero siempre bajo un riguroso respeto al medio y garantizando la conservación de las especies ${ }^{66}$. Respecto a la caza, se indicaba en qué época no se podían cazar conejos o perdices ${ }^{67}$. En cuanto a la pesca, se protegían los recursos piscícolas y se prohibía pescar truchas o cualquier género de peces en el periodo de reproducción (cuando los peces desovan) y en el tiempo de cría, que para las truchas era desde principios de octubre hasta mediados de diciembre y para el resto de peces, desde abril hasta final de mayo. Se marcaban, por tanto, cuáles eran los meses en los que se podía pescar y en cuáles estaba prohibido ${ }^{68}$.

Por su parte, en las "Ordenanzas de Málaga" de 1611 también se contenían disposiciones dirigidas a regular la pesca, el oficio de pescador, el de palangrero y la venta del pescado, lo cual resulta lógico si se tiene en cuenta la importancia del

\footnotetext{
${ }^{61}$ Ibíd., Ordenanzas de las aguas sucias, fols. cclxxviii r-cclxxviii v.

${ }^{62}$ Ibíd., Ordenanzas de las aguas sucias, fol. cclxxviii v.

${ }^{63}$ Fueron confirmadas por Felipe II en 1580. Véase DE LA Cruz Aguilar, Emilio, Ordenanzas del Común de la villa de Segura y su Tierra de 1580 (Instituto de Estudios Giennenses de la Diputación Provincial, 1980). Recoge y comenta brevemente estas ordenanzas JAQUENOD MartíneZ, Silvia Susana, cit. (n. 10), pp. 80-83.

${ }^{64}$ Se establecía la forma de aprovechar el arbolado de los montes, que pertenecía a todos los vecinos del Común, sin que pudiese ser utilizado por los extranjeros, ni siquiera si eran contratados por los vecinos. Se exigía aprovechar todos los pinos que se talasen, se regulaba la época de recogida de los frutos y se prohibía sacar madera fuera del Común de Segura sin licencia del Concejo, siendo obligatorio el trueque de la madera que saliese por determinados productos alimenticios que solían escasear. Se trataban de proteger los barbechos, cuando había llovido recientemente, de los daños ocasionados por el paso de los ganados ("Ordenanzas del Común de la Villa de Segura y su Tierra" de 1580, capítulo 49).

65 “Ordenanzas del Común de la Villa de Segura y su Tierra” de 1580, capítulo 50.

${ }^{66}$ Ibíd., capítulos 69-72.

${ }^{67}$ Ibíd., capítulo 69.

${ }^{68}$ Ibíd., capítulo 72.
} 
mar y sus recursos para la ciudad. Entre ellas, encontramos normas igualmente encaminadas a tutelar la especie piscícola. En concreto, se detienen en la pesca con nasa, obligando a los que la utilizasen a que fuera supervisada por los alcaldes encargados de dicho cometido que debían comprobar que las mallas fuesen de tal forma que cupiesen "por ellas dos dedos" para que las crías no cayesen en las mismas. El incumplimiento se sancionaba con seiscientos maravedís y la pérdida de las nasas, siendo destinada la mitad de la multa al denunciante y la otra mitad a los "propios de la ciudad"69. Con el mismo fin de proteger las crías de los peces, los alcaldes tenían que revisar las redes usadas por las jábegas para el copo, siendo, en esta ocasión, la medida "el dedo segundo de la mano", tomando como referencia una sortija ${ }^{70}$. Del mismo modo, se establecía la prohibición de pescar, tanto con nasa como con jábega, desde el día de Pascua hasta el de San Miguel, para permitir la reproducción de la especie, imponiéndose la misma pena señalada antes, repartida de idéntica manera, salvo licencias especiales para la pesca de la "anchova" (lo que hoy conocemos como boquerón o anchoa) ${ }^{71}$. En caso de que el copo arrastrase crías, debían ser devueltas al agua, incurriendo, en caso contrario, en la misma sanción ${ }^{72}$.

Mayor implicación medioambiental, aunque orientado al entorno en su conjunto más que a las aguas, tendría el título que las ordenanzas malagueñas dedicaban a la limpieza de la ciudad y, en concreto, la disposición que prohibía construir en la calle letrina descubierta o un caño de la misma, bajo pena de sesenta maravedís y la obligación de cubrirla a costa de quien la hizo ${ }^{73}$. Asimismo, se contenía la interdicción de arrojar "bacines" con suciedad a la calle (imponiéndose idéntica multa y el deber de limpiar ${ }^{74}$ ), y, en general, basura, estiércol o inmundicia, siendo, en este último caso, la sanción de doce maravedís ${ }^{75}$. Sí que incidía directamente en la contaminación de las aguas la prohibición de echar "cosa muerta" en la orilla

69 “Ordenanzas de la muy noble y muy leal ciudad de Málaga” de 1611, título Armadores, Naseros y Pescadores (edición facísmil, Málaga, 1996), p. 22v.

${ }^{70}$ Se imponía idéntica sanción y forma de reparto que la señalada anteriormente ("Ordenanzas de Málaga” de 1611, título Armadores, Naseros y Pescadores, p. 23r).

${ }^{71}$ Se dice expresamente "porque el pescado se crie desde el paraje de Torremolinos hasta la cueva de las palomas" "“Ordenanzas de Málaga” de 1611, título Armadores, Naseros y Pescadores, p. 23r).

72 “Ordenanzas de Málaga” de 1611, título Armadores, Naseros y Pescadores, p. 23r. Hay una disposición específica dedicada a la "anchova", a su tratamiento y embarrilado con cierta repercusión medioambiental (aunque escape a nuestro objetivo en esta sede), ya que obligaba a hacerlo en los percheles, prohibiendo que se hiciera en la ciudad o sus arrabales por el mal olor que se producía y la suciedad que podría ocasionar en las calles y casas ("Ordenanzas de Málaga" de 1611, título Ordenanças de lo que toca a la anchova, y del fiel della, y de los varriles, y marca, $e$ toneleros que los hizieren, pp. 23v-25r, ad casum 23v). Véase también el título Alcayde y Corralero del Matadero, donde se presta atención a la limpieza para evitar malos olores, pp. 29v-33r.

${ }^{73}$ Ibíd., título Las ordenanzas que la ciudad manda que guarden sobre la limpieza de la ciudad e sus arrabales, p. $37 \mathrm{r}$.

${ }^{74}$ Ibíd., título Las ordenanzas que la ciudad manda que guarden sobre la limpieza de la ciudad e sus arrabales, p. $37 \mathrm{r}$.

${ }^{75}$ Ibíd., título Las ordenanzas que la ciudad manda que guarden sobre la limpieza de la ciudad e sus arrabales, p. $37 \mathrm{r}$. 
del mar (aparte de en otros lugares), estableciéndose la pena en función del tipo de animal y con independencia de su tamaño: sesenta maravedís, si se trataba de bestia; veinte si era un perro, gato u otro animal y doce, en el caso de una gallina o cualquier ave ${ }^{76}$. Con idéntica finalidad, los pescadores no podían dejar morralla, ni boquerones, ni ningún otro pescado o restos de la pesca en la orilla del mar, salvo que luego lo recogiesen. En este supuesto, la pena se elevaba a doscientos maravedís junto con la obligación de limpiar ${ }^{77}$. De forma más genérica, se impedía arrojar basuras e inmundicias en la orilla del río Guadalmedina o del mar y en cualquier parte, salvo en los lugares destinados al efecto, siendo la multa de un real por cada "carga" y la exigencia de retirarlo ${ }^{78}$. La acción de verter agua sucia a la calle por ventana, terraza o agujero se castigaba con doscientos maravedís y si era agua limpia, había que avisar tres veces con antelación para evitar los daños ${ }^{79}$. Cuando se llevaba a cabo el saneamiento de alcantarillas, letrinas o pozos, cañerías o sumideros no se podían dejar las inmundicias en la calle salvo licencia y, aun teniendo dicha licencia, se debían recoger y llevar fuera al día siguiente, bajo pena de seiscientos maravedís y la consiguiente limpieza ${ }^{80}$.

En materia de riego ${ }^{81}$, hay que destacar la figura del alcalde del agua. Se nombraban uno o dos a elección de la ciudad y tenían que prestar juramento solemne requerido al efecto. No podían cobrar más que los derechos y el salario tasado, siendo sancionados, en caso contrario, con seiscientos maravedís ${ }^{82}$. Sus funciones serían las establecidas en las propias ordenanzas. Debían tener un libro donde constasen los pagos, las huertas, las tierras y las viñas de regadío, con el fin de hacer el reparto de las aguas en condiciones de igualdad, dependiendo de la tierra y de lo que se hubiese sembrado. Otro libro similar quedaba en manos del escribano del Concejo ${ }^{83}$. La forma de regar se regulaba de manera minuciosa, siguiendo una ordenanza previa. De los cauces por donde eran conducidas las aguas hasta los molinos, se podía tomar agua para regar los lunes y jueves de cada semana y, tras la puesta del sol, se debían cerrar dichos cauces y acequias para que aquélla volviese a su cauce original, sancionándose el incumplimiento de esta norma con doscientos maravedís, la mitad para los propios de la ciudad y la otra mitad para

\footnotetext{
${ }^{76}$ Ibíd., título Las ordenanzas que la ciudad manda que guarden sobre la limpieza de la ciudad e sus arrabales, p. $37 \mathrm{v}$.

${ }^{77}$ Ibíd., título Las ordenanzas que la ciudad manda que guarden sobre la limpieza de la ciudad e sus arrabales, p. $37 \mathrm{v}$.

${ }^{78}$ Ibíd., título Las ordenanzas que la ciudad manda que guarden sobre la limpieza de la ciudad e sus arrabales, p. $37 \mathrm{v}$.

${ }^{79}$ Ibíd., título Las ordenanzas que la ciudad manda que guarden sobre la limpieza de la ciudad e sus arrabales, p. $37 \mathrm{v}$.

${ }^{80}$ Ibíd., título Las ordenanzas que la ciudad manda que guarden sobre la limpieza de la ciudad e sus arrabales, p. 38r.

${ }^{81}$ Queda al margen de nuestro objetivo analizar la regulación del riego dirigida, sobre todo, a proteger las principales cosechas en época de sequía, pero sí recogemos algunas disposiciones por cuanto imponen, como veremos, la obligación de limpiar los cauces y acequias, lo que sí incide directamente en materia de contaminación.

${ }^{82}$ Ibíd., título En lo que toca a los árboles y al agua, pp. 110r-110v.

${ }^{83}$ Ibíd., título En lo que toca a los árboles y al agua, p. 110v.
} 
el denunciante, doblándose la pena en caso de reincidencia ${ }^{84}$. No obstante, como lo anterior se dispuso, al parecer, en época de abundancia de agua, se establecía, para proteger el bien universal del riego y, sobre todo, las cosechas de trigo que, en años de sequía, los señores de tierras y heredades donde hubiese que sembrar o que tuviesen sembrado trigo, cebada o panizo podían utilizar el agua el domingo, martes, jueves y sábado de cada semana, devolviéndola luego a su cauce principal. Los que hacían uso de este derecho de riego tenían que limpiar convenientemente las acequias y entradas de agua en sus respectivas tierras cuando se lo ordenasen los alcaldes del agua, bajo pena de doscientos maravedís, la mitad para los propios de la ciudad y la otra mitad para dichos alcaldes, junto con la limpieza a costa del incumplidor ${ }^{85}$. Se declaraba que todas las fuentes y el agua de la ciudad eran para el riego y el uso común de tierras, heredades y molinos y ninguna persona podía obstaculizar el ejercicio de este derecho ni impedir los cauces, acequias, caminos o hijuelas por donde se regaban dichas tierras, siendo, en tal caso, la multa de doscientos maravedís que se repartirían de igual forma, la mitad para los propios de la ciudad y la otra mitad para los alcaldes del agua ${ }^{86}$. Se insistía en que el que tomaba agua para regar, según el reparto hecho por los alcaldes, la devolviese "a la madre principal" y la cerrase para evitar pérdidas, imponiéndose idéntica sanción ${ }^{87}$. En cualquier caso, a la hora de utilizar el agua, siempre se había de estar a lo establecido por los referidos alcaldes para que no hubiese desorden ni discriminación, señalándose la misma pena de doscientos maravedís, repartida de manera similar, para el que tomaba agua que perteneciese a otro ${ }^{88}$, no siendo necesarios testigos para probar este hecho sino la simple comprobación por los alcaldes ${ }^{89}$. También se regulaba la forma de plantar árboles cerca de las acequias y cauces destinados a regar heredades y se prohibía causar daño con ganado o de cualquier otro modo en dichos cauces y acequias ${ }^{90}$ o curar lino o cáñamo ${ }^{91}$, aunque se debía facilitar la llegada del ganado a los abrevaderos y la provisión de éstos ${ }^{92}$.

En las diversas ordenanzas de la comarca de Liébana descubrimos disposiciones relacionadas con el deber de mantener limpias, además de las calles, plazas,

${ }^{84}$ Ibíd., título En lo que toca a los árboles y al agua, p. 110v.

${ }^{85}$ Ibíd., título En lo que toca a los árboles y al agua, pp. 110v-111r.

${ }^{86}$ Ibíd., título En lo que toca a los árboles y al agua, p. $111 \mathrm{r}$.

${ }^{87}$ Ibíd., título En lo que toca a los árboles y al agua, p. $111 \mathrm{r}$.

${ }^{88} \mathrm{Ibíd}$., título En lo que toca a los árboles y al agua, p. $111 \mathrm{r}$.

${ }^{89}$ Ibíd., título En lo que toca a los árboles y al agua, p. $111 \mathrm{v}$.

${ }^{90}$ Ibíd., título En lo que toca a los árboles y al agua, p. $111 \mathrm{v}$.

${ }^{91}$ Ibíd., título En lo que toca a los árboles y al agua, p. 112r.

${ }^{92}$ En este particular no se indica nada sobre la limpieza (Ibíd., título En lo que toca a los erbajes, pastos, pp. 116v-117r). La regulación, en la que no vamos a entrar, es minuciosa en cuanto al paso de ganados y lugares donde podían o no pastar o abrevar. En concreto, se prohibía llevar cerdos al Guadalmedina (Ibíd., título En lo que toca al coger de la bellota, p. 123v). 
vías y caminos ${ }^{93}$, las fuentes y cursos de aguas ${ }^{94}$. El incumplimiento se castigaba, normalmente, con una multa y la obligación de limpiar lo que se había ensuciado. Así, en las "Ordenanzas de la Villa de Potes", de 15 de enero de 1468, se establecía el lugar exacto del río donde podían trabajar los zapateros o donde las mujeres tenían que lavar las tripas, para proteger sus aguas. Posteriormente, en las ordenanzas de la misma villa de 1619, se prohibía que los zapateros adobasen o rayasen cueros en los ríos principales, salvo en el pozo de Las Vegas hacia abajo $\mathrm{y}$, con carácter general, que cualquiera arrojase "lino a mojo" en los ríos, salvo en lugares concretos, bajo pena de doscientos maravedís, cien para la Villa y de los otros cien, la mitad para el juez ejecutor y la otra para el denunciante ${ }^{95}$. Con el fin de evitar daños en las tierras, más que para garantizar la salubridad de las aguas, se obligaba a los vecinos, cuya finca lindase con una madre de agua o pasase por ella, a que la limpiasen para que el agua no reventase hacia su heredad ni hacia otras. La inobservancia de esta obligación se castigaba con la reparación de los daños y una multa de doscientos maravedís destinados al Concejo de la villa ${ }^{96}$. Además, se establecía que las fuentes debían estar limpias y no se podía lavar en ellas ni carne, ni ropa, ni pescado, ni echar suciedad alguna, siendo la sanción de cien maravedís por cada vez que se hiciera. El agua se tenía que tomar por estricto orden de llegada bajo pena de un real para el que alterase dicho orden ${ }^{97}$. Las "Ordenanzas del Concejo de Baró" de 1620 exigían la limpieza de los prados y que los regidores hicieran desinfectar una vez al año las madres de las aguas ${ }^{98}$. Igualmente, se disponía que las fuentes estarían "bien aderezadas" todo el año, y sus canales "bien arreglados" y el que las tuviese "poco limpias" tenía que abonar al Concejo cien maravedís". Especial atención se prestaba a la pesca en los "Capítulos de Buen Gobierno de Lon y Brez” de 1602, en relación a la prohibición de pescar en determinados meses o a la medida de las redes ${ }^{100}$. Además de incidir

93 "Ordenanzas de la Villa de Potes" de 15 de enero de 1468, capítulo 21; "Ordenanzas de la Villa de Potes" de 1619, capítulos 40, 41 y 47; "Ordenanzas del Concejo de Baró” de 1739, capítulo 45; "Capítulos de Buen Gobierno de Lon y Brez” de 1594, capítulo 12 [PÉrEZ Bustamante, Rogelio - Baró Pazos, Juan, El Gobierno y la Administración de los pueblos de Cantabria, I, Liébana (Diputación regional de Cantabria, Universidad de Cantabria, Santander, 1988), pp. 24, 55 y 57, 119 y 173$]$.

94 "Ordenanzas de la Villa de Potes", de 15 de enero de 1468, capítulos 29 y 30 [PÉrez Bustamante, Rogelio - Baró Pazos, Juan, cit. (n. 93), pp. 25-26].

${ }^{95}$ Ibíd., de 1619, capítulo 30 [Pérez Bustamante, Rogelio Baró Pazos, Juan, cit. (n. 93), p. 50].

${ }^{96}$ Ibíd., de 1619, capítulo 40 [Pérez Bustamante, Rogelio - Baró Pazos, Juan, cit. (n. 93), p. 54].

${ }^{97}$ Ibíd., de 1619, capítulo 48 [Pérez Bustamante, Rogelio - Baró Pazos, Juan, cit. (n. 93), p. 57].

98 "Ordenanzas del Concejo de Baró" de 1620, capítulos 16 y 17 [Pérez Bustamante, Rogelio - Baró Pazos, Juan, cit. (n. 93), p. 103].

99 “Ordenanzas del Concejo de Baró” de 1620, capítulo 25 [PÉrez Bustamante, Rogelio Baró Pazos, Juan, cit. (n. 93), p. 105].

100 "Capítulos de Buen Gobierno de Lon y Brez" de 1602, capítulos 13 y 15 [PÉrez Bustamante, Rogelio - Baró Pazos, Juan, cit. (n. 93), pp. 181-182]. 
en la limpieza de los montes ${ }^{101}$, en el deber de enterrar a los animales ${ }^{102}$ y de evitar los malos olores ${ }^{103}$, se obligaba a sanear y reparar las calles públicas, puentes y manantiales, bajo pena de quinientos maravedís ${ }^{104}$. Las "Ordenanzas de los Concejos de Mogrovejo y Tanarrio” de 1739 recogían la obligación de limpiar y aderezar la fuente de Luarna con el fin de garantizar el agua (y entendemos que su salubridad) para el Concejo ${ }^{105}$. Asimismo, se ordenaba la desinfección de la "madre del agua" ${ }^{106}$. Del reparto del agua para el riego procedente del río Monterón, se ocupaban las "Ordenanzas de Enterrias, Vada y Dobarganes” de 1744. Se indicaba cuándo se debía sacar y la necesidad de hacer una presa para prevenir el desperdicio, castigándose el incumplimiento con doscientos maravedís ${ }^{107}$. Además, se prohibía que, una vez extraída el agua, cualquier vecino o forastero se aprovechase de ella para el riego de los prados hasta entrar en la pradería de "So Enterrias" y, una vez allí, los regidores tenían que nombrar a dos vecinos para que hicieran el reparto, por días o por horas, dependiendo de los prados de cada uno y el que no respetase los turnos debía pagar al Concejo doscientos maravedís ${ }^{108}$. Cada vecino tenía que limpiar la madre del agua de su heredad para que el agua corriese sin problema hasta el río, quedando expresamente prohibido echar piedras en la misma, bajo pena de cien maravedís ${ }^{109}$. La misma obligación de que los cauces estuviesen sin piedras todo el año se recogía en las "Ordenanzas del Concejo de Toranzo" de 1782 , con idéntica sanción ${ }^{110}$. Se disponía que cada vecino debía hacer un pozo en su finca que le garantizase el agua necesaria durante todo el año, siendo preciso que lo mantuviese limpio. La pena en caso de incumplimiento era de cien maravedís, la misma que se imponía por lavar en las fuentes concejiles ${ }^{111}$ o por no limpiar los manantiales donde bebía el ganado $182]$.

${ }^{101}$ Ibíd., capítulo 17 [Pérez Bustamante, Rogelio - Baró Pazos, Juan, cit. (n. 93), p.

${ }^{102}$ Ibíd., capítulo 18 [Pérez Bustamante, Rogelio - Baró Pazos, Juan, cit. (n. 93), p. $182]$.

${ }^{103}$ Ibíd., capítulo 19 [Pérez Bustamante, Rogelio - Baró Pazos, Juan, cit. (n. 93), p. 182]. $182]$

${ }^{104}$ Ibíd., capítulo 16 [Pérez Bustamante, Rogelio - Baró Pazos, Juan, cit. (n. 93), p.

105 "Ordenanzas de los Concejos de Mogrovejo y Tanarrio" de 1739, capítulo 40 [Pérez Bustamante, Rogelio - Baró Pazos, Juan, cit. (n. 93), p. 208]. Véase también capítulos 99, 103 y 106 donde se ordenaba limpiar caminos y dehesas (pp. 220, 221 y 222).

${ }^{106}$ Ibíd., capítulo 147 [Pérez Bustamante, Rogelio y Baró Pazos, Juan, cit. (n. 93), p. 230].

107 “Ordenanzas de Enterrias, Vada y Dobarganes” de 1744, capítulo 37 [Pérez BustamanTe, Rogelio y Baró Pazos, Juan, cit. (n. 93), pp. 270-271].

${ }^{108}$ Ibíd., capítulo 38 [Pérez Bustamante, Rogelio y Baró Pazos, Juan, cit. (n. 93), p. 271].

${ }^{109}$ Ibíd., capítulo 41 [Pérez Bustamante, Rogelio y Baró Pazos, Juan, cit. (n. 93), p. 271]. También se prohibía echar piedras en los campos, caminos y calles públicas (capítulo 42, p. 272).

110 "Ordenanzas del Concejo de Toranzo" de 1782, capítulo 14 [Pérez Bustamante, Rogelio y Baró Pazos, Juan, cit. (n. 93), p. 306].

${ }^{111}$ Ibíd., capítulo 37 [Pérez Bustamante, Rogelio y Baró Pazos, Juan, cit. (n. 93), p. $313]$. 
en verano ${ }^{112}$. La preocupación por la limpieza de las fuentes era una constante en las ordenanzas que nos ocupan. Así, en las del Concejo de Tudes de 1591 se señalaba que cada año los regidores de dicho Concejo debían exigir a los vecinos que saneasen los manantiales y pozos y, si no lo hacían, se les impondría la pena de un real ${ }^{113}$. Una multa de cien maravedís se establecía para el que lavase carne o ropa en las fuentes de Encalada y el Puma, según las "Ordenanzas del Concejo de Bejes" de $17399^{114}$. Por su parte, las "Ordenanzas del Concejo de Valmeo" de 1701 disponían la limpieza de los conductos del agua para el riego del barrio de San Andrés, que era extraída de la riega del mismo nombre, el uno de marzo de cada año ${ }^{115}$. Al saneamiento de los abrevaderos, se referían las "Ordenanzas del Concejo de Armaño" de $1751^{116}$ y al mantenimiento de caminos, fontanas, calzadas y pasos reales, obligaban los Capítulos de Buen Gobierno de Buyezo de 1605, bajo pena de seiscientos maravedís ${ }^{117}$, mientras que los de 1617 ordenaban limpiar y reparar con cuidado las fuentes ${ }^{118}$ y los caminos públicos y reales del Concejo ${ }^{119}$. La reparación de caminos, fuentes y puentes era el destino principal del importe de las multas que se cobraban por infracción de las "Ordenanzas del Concejo de Cabezón” de 1624 , salvo que los regidores decidiesen otra cosa ${ }^{120}$. También se preocupaban del cuidado de caminos, fontanas y puentes, imponiéndose una pena de cien maravedís en caso de infracción, las "Ordenanzas de La Vega" de $1739^{121}$. Prohibición expresa de lavar ropa o carne en las fuentes se contenía en las "Ordenanzas del Concejo de Avellanedo" de $1618^{122}$.

Aunque no llegó a entrar en vigor, no podemos obviar, por su trascendencia e influjo en normas posteriores, El Tratado breve sobre las ordenanzas de la villa de Madrid y policía de ella, del arquitecto Juan de Torija, quien se remonta a $313]$.

${ }^{112}$ Ibíd., capítulo 148 [Pérez Bustamante, Rogelio y Baró Pazos, Juan, cit. (n. 93), p.

113 “Ordenanzas del Concejo de Tudes" de 1591, capítulo 34 [Pérez Bustamante, Rogelio y Baró Pazos, Juan, cit. (n. 93), p. 338].

114 "Ordenanzas del Concejo de Bejes" de 1739, capítulo 24 [Pérez Bustamante, Rogelio y Baró Pazos, Juan, cit. (n. 93), p. 422]. Sobre la limpieza de caminos, fuentes y puentes, Véase capítulo 22, p. 422 y de las albercas, capítulo 46, p. 427. También se establecía la forma de conducir el agua para evitar perjuicios (capítulo 55, p. 429).

115 "Ordenanzas del Concejo de Valmeo" de 1701, capítulo 4 [Pérez Bustamante, Rogelio y Baró Pazos, Juan, cit. (n. 93), pp. 355-356].

116 "Ordenanzas del Concejo de Armaño" de 1751, capítulo 9 [Pérez Bustamante, Rogelio y Baró Pazos, Juan, cit. (n. 93), p. 396].

117 "Capítulos de Buen Gobierno de Buyezo" de 1605, capítulo 9 [Pérez Bustamante, Rogelio y Baró Pazos, Juan, cit. (n. 93), p. 569].

118 "Capítulos de Buen Gobierno de Buyezo" de 1617, capítulo 5 [Pérez Bustamante, Rogelio y BARÓ PAZZos, Juan, cit. (n. 93), p. 572].

${ }^{119}$ Ibíd., capítulo 6 [Pérez Bustamante, Rogelio y Baró Pazos, Juan, cit. (n. 93), p. $572]$.

120 “Ordenanzas del Concejo de Cabezón” de 1624, capítulo 55 [Pérez Bustamante, Rogelio y Baró Pazos, Juan, cit. (n. 93), p. 657].

121 "Ordenanzas de la Vega" de 1739, capítulo 33 [Pérez Bustamante, Rogelio y Baró Pazos, Juan, cit. (n. 93), p. 374].

122 "Ordenanzas del Concejo de Avellanedo" de 1618, capítulo 129 [Pérez Bustamante, Rogelio y Baró Pazos, Juan, cit. (n. 93), p. 699]. 
Marco Vitruvio Pollio y a su obra De architectura (c. 27 a. C.). Se ocupaba de los albañales o canales que daban salida a las aguas fecales y de los condutales que vaciaban las aguas pluviales. Prohibía que las aguas inmundas de un vecino fuesen conducidas a la casa de otro vecino porque se podían ocasionar daños en los cimientos o paredes, debido a las humedades, y por una cuestión higiénicosanitaria ya que los vapores y malos olores causaban enfermedades. Por estos motivos, se le debía dar salida a la calle a costa del vecino damnificado que era el que resultaba beneficiado, salvo en los casos de servidumbre ${ }^{123}$. Problema distinto era el de los albañales o condutales que se acercaban a las paredes medianeras, estableciéndose la distancia que tenía que existir para evitar que se calase la pared del vecino ("a lo menos un pie hasta el condutal de en medio"). Además, se exigía que estuviesen suficientemente protegidos con cal y arena para eludir las humedades ${ }^{124}$. Se admitían los condutales de piedra arrimados a las paredes, así como cerrar los medianeros, siempre que se hiciese en la forma prevista que se detallaba en cuanto al ancho, fondo, juntas... para impedir que las inmundicias de los zaguanes (debido al "poco aseo de los vecinos") provocasen inundaciones y filtraciones ${ }^{125}$. Cuando en una casa era imposible que las aguas saliesen al exterior, se permitía construir un sumidero, siempre que se hiciese en medio del patio o del corral, tuviese un diámetro de dos pies y se fuese ensanchando hacia abajo en forma de campana. Si el propietario no tenía capacidad para hacerlo en la forma establecida, al menos, estaba obligado a apartarlo de las medianerías seis pies y si los cimientos de los medianeros sufrían algún detrimento a causa del sumidero se le exigía reparar los daños ocasionados. Respecto a los pozos, el sumidero tenía que estar a una distancia de doce pies y fortalecido, ya que las aguas que normalmente se recogían en estos sumideros solían estar muy contaminadas por las inmundicias y el cieno pudiendo infectar las habitaciones de las viviendas y este agua corrompida podía filtrarse al pozo y contaminar el agua destinada al consumo $^{126}$. Se contenían una serie de advertencias e instrucciones a seguir a la hora de fabricar pozos, relativas a su ubicación, forma o distancia de las paredes medianeras o de otro pozo para imposibilitar el hurto del agua ${ }^{127}$. Se planteaba el problema de las letrinas comunes necesarias sobre todo en las comunidades de religiosos y religiosas. En cualquier caso, se tenían que situar de forma que el aire no llevase los vapores a las habitaciones, y apartadas diez pies de las medianerías, a no ser que el sitio fuese demasiado estrecho, bastando, en tal supuesto, seis pies. Si existía previamente un pozo, en lo más profundo de la letrina había que hacer una pared de cal y canto de tres pies de grosor, con el fin de impedir que se transmitiesen olores fétidos o vapores a los pozos vecinos. Asimismo, si estaban

${ }^{123}$ DE TORIJA, Juan, Tratado breve sobre las ordenanzas de la villa de Madrid y policía de ella (Madrid, 1661), capítulo V.

${ }^{124}$ Ibíd., capítulo VI.

${ }^{125}$ Ibíd., capítulo VII.

${ }^{126}$ Ibíd., capítulo VIII.

${ }^{127}$ Ibíd., capítulo IX. Véase también lo dispuesto sobre los requisitos para la construcción de norias, estanques o pilones para impedir los daños a las paredes medianeras [DE TORIJA, Juan, cit. (n. 123), capítulos XI y XII]. 
en un sitio elevado con salida a ríos o arroyos, sus minas tenían que ser anchas para que por ellas se expeliesen las inmundicias o vapores. Se exigía la limpieza anual ${ }^{128}$. Se prohibía tirar excrementos en los callejones que quedasen entre dos casas vecinas, ya que no solo dañaban las paredes, sino que también provocaban enfermedades debido a la putrefacción de la tierra, y el que contravenía lo dispuesto era multado y obligado a reparar los deterioros de las paredes y a limpiar a su costa. Del mismo modo, los vecinos tenían que desinfectar el callejón dos veces al año para evitar que vapores nocivos llegasen a las habitaciones ${ }^{129}$. No se permitía que tuviesen canalones de madera por los que arrojar inmundicias a la calles por los perjuicios que se causaban a los transeúntes ${ }^{130}$.

El arquitecto Teodoro Ardemans preparó una nueva edición de estas ordenanzas en 1719 que tampoco entró en vigor ${ }^{131}$. Se recogían unas "advertencias comunes para la seguridad de la buena habitación” donde se contenían una serie de interesantes recomendaciones sobre la distribución de las habitaciones, la forma de construir viviendas, su ubicación, ventilación, orientación, chimeneas y calidades, con el fin último, entre otros, de evitar enfermedades, es decir, conseguir edificios $\operatorname{sanos}^{132}$. Entre ellas, figuraban medidas de naturaleza higiénico-sanitaria como la necesidad de buscar una zona donde el aire fuese limpio y puro, huyendo del "aire pestifero producido de nieblas espesas, o fumosidad de la tierra, ocasionada de humedad, calor o frío y del mal olor" y, sobre todo, lejos de aguas sucias o estan$\operatorname{cad}^{133}{ }^{133}$. Se debía procurar que los dormitorios no tuviesen la pared de cabecera contigua a algún albañal, pozo, fuente, sumidero o arca de agua y se advertía que todo albañal que pasara por una habitación, aunque estuviese debidamente tapado con losas o tablones, podría tener consecuencias negativas en la salud del

${ }^{128}$ Ibíd., capítulo X.

${ }^{129}$ Ibíd., capítulo XVII.

${ }^{130}$ Ibíd., capítulo XLIII. Se detalla la forma en la que debían construirse los vertederos para las inmundicias y la obligación de comprobar si pasaba gente y avisar antes de echarlas a la calle.

${ }^{131}$ ARdemans, Teodoro, Declaración y extensión sobre las Ordenanzas que escribió Juan de Torija, Aparejador de obras Reales y de las que se practican en las Ciudades de Toledo y Sevilla, con algunas advertencias, a los Alarifes y Particulares, y otros capitulos añadidos a la perfecta inteligencia de la materia, que todo se cifra en el Gobierno Político de las Fábricas (Madrid, Plácido Barco López, 1796). Hemos seguido otra edición que lleva por título Ordenanzas de Madrid y otras diferentes que se practican en las ciudades de Toledo y Sevilla, con algunas advertencias, a los Alarifes y Particulares, y otros Capitulos añadidos a la perfecta inteligencia de la materia, que todo se cifra en el Gobierno Político de las Fábricas, aumentado en esta última impresión con el Bando sobre incendios, publicado en Madrid el 8 de noviembre del año de mil setecientos noventa (Madrid, Imprenta de Don Joseph Doblado, 1791). Hay otra edición anterior de A. Pérez de Soto a expensas de Pedro Joseph Alonso y Padilla de 1760. Cfr. Navascués Palacios, Pedro, Introducción al desarrollo urbano de Madrid hasta 1830, en Madrid, testimonios de su historia (Museo Municipal, 1979), pp. 15-26, en p. 18. Véase Blanco Esquivias, Beatriz, Teodoro Ardemans y su entorno en el cambio de siglo (1661-1726). Aspectos de la arquitectura y el urbanismo madrileños de Felipe II a Carlos III (Madrid, Universidad Complutense, 1991).

${ }^{132}$ IвíD., Tercer proemial, pp. 41-49.

${ }^{133}$ Se habla de "aguas de lagunas sucias, aquellas que carecen de movimiento, y en su quietud se pudren, resultando de ellas las pestes estribales de tabanos, mosquitos, gusanos y otras sabandijas muy perjudiciales" (IBÍD., Tercer proemial, p. 42) 
que allí viviese ${ }^{134}$. Se insistía, en varias ocasiones, en la conveniencia de impedir las humedades y sumideros dentro de la propia vivienda, debiendo dar salida a las aguas al exterior, porque aquéllos solo servían "de albergue a quantas malas y perjudiciales sabandijas hay contrarias a la salud" 135 . Especial cuidado se tendría en la limpieza de los referidos albañales y sumideros para que las aguas inmundas no afectasen a la salud ${ }^{136}$. Siempre que una alcantarilla fuese por debajo de la casa, aunque estuviese lo suficientemente profunda, podía provocar emanaciones y vapores nocivos, debiendo evitarse esta situación en la medida de lo posible ${ }^{137}$, así como construir la vivienda cerca de desagües de aguas fecales, de vertederos, de estercoleros o de hospitales ${ }^{138}$. Mayor extensión tenían las disposiciones relativas al "Gobierno político de las fábricas" donde se establecían pautas en torno al modo de construir como, por ejemplo, la altura de los edificios ${ }^{139}$, el problema de las aguas que vertían en el tejado vecino que debían reconducirse a la calle ${ }^{140}$, las paredes o las casas medianeras ${ }^{141}$, los edificios a distintas alturas ${ }^{142}$, la distancia entre las casas para permitir la salida de las aguas ${ }^{143}$, la manera de fabricar hornos para no afectar al vecino ${ }^{144}$, las ventanas de medianería ${ }^{145}$, las puertas de cocheras en calles públicas $^{146}$, las cuevas ${ }^{147}$, los balcones ${ }^{148}$, las fraguas y otros oficios perjudiciales ${ }^{149}$, las lumbreras de sótanos y cuevas ${ }^{150}$, las obras y reparaciones de los molinos que

${ }^{134}$ Ibíd., Tercer proemial, p. 45.

${ }^{135}$ Ibíd., p. 46.

${ }^{136}$ Ibíd., pp. 48-49.

${ }^{137}$ Ibíd., p. 49.

${ }^{138}$ Ibíd., p. 49.

${ }^{139}$ Ibíd., capítulo II, pp. 51-52.

${ }^{140}$ Ibíd., capítulo III, pp. 53-58. Si, en algún caso, fuese necesario hacer un sumidero para recoger las aguas, se debía limpiar siempre que fuese preciso a costa de los vecinos, aunque era preferible construir un canal subterráneo a cargo de todos los interesados para dar salida al agua y evitar que se quedase en el centro de la casa, ya que esto podría resultar perjudicial tanto para la salud como para el propio edificio (pp. 57-58).

${ }^{141}$ Ibíd., capítulos IV y V, pp. 58-67.

${ }^{142}$ Ibíd., capítulo VI, pp. 68-69.

${ }^{143}$ Ibíd., capítulo IX, pp. 78-79. Se exigía que los callejones que quedaban entre los edificios se limpiasen cada quince días para impedir los malos olores y que tuviesen el suficiente desnivel para que corrieran las aguas.

${ }^{144}$ Ibíd., capítulo X, pp. 80-83.

${ }^{145}$ Ibíd., capítulo XI, pp. 84-88.

${ }^{146}$ Ibíd., capítulo XII, pp. 88-90.

${ }^{147}$ Ibíd., capítulo XIII, pp. 90-93.

${ }^{148}$ Ibíd., capítulo XIV, pp. 93-95.

${ }^{149}$ Ibíd., capítulo XVIII, pp. 106-109. En concreto, se especificaba que los tintoreros debían llevar las aguas de los tintes "medio quarto de legua a verterlas" porque eran muy perjudiciales para la salud de los vecinos por los vapores que emanaban (p. 108). Tampoco los cosecheros de las viñas podían verter en las vías públicas las cubas ni los restos de las tinajas donde aclaraban el vino porque al mezclarse con las suciedad de las calles resultaba una mezcla poco salubre (pp. 108-109).

${ }^{150}$ Ibíd., capítulo XIX, pp. 109-110. 
pertenecían a varios propietarios ${ }^{151}$, las buhardillas ${ }^{152}$, los materiales para las obras $^{153}$ e incluso la organización de la plaza mayor para las fiestas de toros ${ }^{154}$. Se aconsejaba no edificar cerca de monasterios para garantizar su intimidad, salvo casos excepcionales (por ejemplo herencia) en los que se prohibían extorsiones por parte de la comunidad como hacer en la medianería un conducto para verter las aguas inmundas ${ }^{155}$. Tal y como indicaba Torija, no se permitían los canalones de madera para hacer vertidos a la calle y, ante la necesidad de que las casas tuviesen un vertedero, se recomendaba uno común o por un callejón o ventana exterior o buhardilla siendo obligado comprobar, antes de su vaciado, la presencia de algún transeúnte ${ }^{156}$. Además, se exigía que se tomasen todas las medidas oportunas para evitar daños a balcones o casas vecinas $y$, aunque la regla general era prohibir dichos canalones o vertederos, si eran imprescindibles se debían hacer de la mejor calidad y en la forma y con las medidas establecidas con el fin de mantener el impulso del agua y no perjudicar a las viviendas situadas enfrente o a las contiguas ${ }^{157}$. En ningún caso se podría efectuar un vertido antes de las diez de la noche ${ }^{158}$. En cuanto a los pozos, no se admitían dentro de las casas y cerca de pared medianera, salvo acuerdo de los vecinos, siendo el aprovechamiento y los gastos comunes. Tampoco se podía hacer pozo cerca del de un vecino, porque el más profundo dejaría seco al otro, siendo precisa una desviación de veinticuatro pies. Esta misma era la distancia en la que se debía situar cualquier sumidero respecto a un pozo para impedir la comunicación de las aguas inmundas a través de la tierra ${ }^{159}$. Había que tener especial cuidado en no verter aguas fecales en los patios por los malos olores y la presencia de insectos, siendo conveniente su limpieza frecuente para prevenir inundaciones ${ }^{160}$. Del mismo modo, las letrinas tenían que estar apartadas de las casas medianeras y cualquier deterioro que se ocasionara correría a cargo del causante con independencia de que se tratase de un particular o de un Monasterio, debiendo estos últimos procurar ubicarlas en los lugares donde fuesen menos perjudiciales y limpiarlas ${ }^{161}$. Al igual que en las

${ }^{151}$ Ibíd., capítulo XX, pp. 111-113. Cualquier canal que se hiciese para el riego debía contar con el consentimiento de todos los propietarios y la limpieza de los mismos sería también a cargo de todos. Cuando un vecino dueño de una heredad quería hacer una presilla en perjuicio de un molino o molinos se debía mantener si existía antes que los molinos, pero no se permitía en caso contrario y lo mismo se indicaba respecto a cualquier otra edificación.

${ }^{152}$ Ibíd., capítulo XXII, pp. 116-118.

${ }^{153}$ Ibíd., capítulo XXIII, pp. 118-130.

${ }^{154}$ Ibíd., capítulo XXIV, pp. 130-138.

${ }^{155}$ Ibíd., capítulo VII, pp. 70-74.

${ }^{156}$ Ibíd., capítulo XV, pp. 96-97.

${ }^{157}$ Ibíd., capítulo XV, pp. 97-98.

${ }^{158}$ Ibíd., capítulo XV, p. 98.

${ }^{159}$ Ibíd., capítulo XVI, pp. 98-99. La distancia era el doble de la indicada por Torija. Al igual que señalaba Torija, se recomendaba no hacer sumideros dentro de las casas pero, en caso de necesidad, debía tener un diámetro de dos pies y ensancharse hacia abajo en forma de campana, dirigiendo las canalizaciones hacia la calle evitando pozos y cuevas (pp. 99-100).

${ }^{160}$ Ibíd., capítulo XVI, p. 100.

${ }^{161}$ Ibíd., capítulo XVI, pp. 100-101. Asimismo, se establecían las distancias a las que se debían situar las norias, estanques o pozas respeto a las medianerías para evitar humedades, 
"Ordenanzas de Torija” se prohibía que las canalizaciones de agua pasaran por la casa del vecino, entre otros motivos, por los daños que se ocasionaban al edificio, sin que cupiese alegar consentimiento tácito por un periodo de diez años ${ }^{162}$. Problema distinto era el del agua que nacía en una finca y pasaba por otras ajenas cuyas circunstancias debían pactarse entre los vecinos y por escrito para evitar conflictos, siendo sancionado el que utilizase el agua sin autorización. Se establecía que cualquier manantial que naciese en una heredad pertenecía al propietario de ésta quien podía venderlo o arrendarlo por días para regar, o encañar el agua y llevarla donde quisiera por sus tierras o por las del vecino con su permiso ${ }^{163}$. Uno de los capítulos más extensos era el dedicado a las fuentes públicas y particulares, aunque la principal preocupación consistía en delimitar exactamente las obligaciones del municipio de Madrid y las de los vecinos respecto a las mismas para prevenir enfrentamientos, sin ninguna alusión a su limpieza. Un problema era la existencia en las calles y plazas de numerosas cañerías públicas y privadas, algunas muy antiguas, que provocan hundimientos y daños diversos, así como el hecho de que, en muchas ocasiones, los vecinos ocupaban con sótanos o cuevas las calles, perjudicando las zonas públicas y sus propias viviendas, exigiéndose, en tales casos, determinadas medidas para reparar o fortalecer las construcciones ${ }^{164}$. El que tuviese fuente en su casa debía procurar que ésta no afectase a las paredes o suelos del vecino medianero, estando obligado a resarcir todos los desperfectos a satisfacción del perjudicado. Si la fuente desaguaba en la calle por canal de piedra o cañería, éstos debían apartarse al menos tres pies de la pared medianera, por su carácter perenne a diferencia de lo que sucedía con las aguas pluviales, siendo todos los gastos a costa del dueño de la fuente ${ }^{165}$. Cuando la cañería pasaba por propiedad ajena era necesario el permiso del vecino (gratuito o por precio) reparando siempre todos los daños ${ }^{166}$. Si eran varios los vecinos de un mismo barrio que tuviesen fuentes en sus casas que recibían el agua de fontana pública, todos estaban compelidos a los arreglos y mantenimientos necesarios ${ }^{167}$. Se advertía de los inconvenientes de que las cañerías principales pasasen por jardines o huertas particulares, exigiéndose limpiarlas de las raíces ${ }^{168}$. Se prohibía utilizar cañerías ajenas para surtir de agua las casas particulares, imponiéndose "grave pena" por dejar las fuentes públicas y particulares en situación de escasez ${ }^{169}$.

corriendo siempre los gastos de reparación de los daños ocasionados a costa del vecino que los provocó (pp. 101-102).

${ }^{162}$ Ibíd., capítulo XVII, pp. 102-103. Si alguien era obligado por la fuerza a recibir las aguas de la casa medianera, podía optar por incluir en el grueso de la pared un sumidero para dar salida a las aguas pluviales, pero no a las fecales ya que éstas eran más perjudiciales para los vecinos por el mal olor y por los insectos (pp. 103-104).

${ }^{163}$ Ibíd., capítulo XXI, pp. 113-116.

${ }^{164}$ Ibíd., capítulo XXV, pp. 138-143.

${ }^{165}$ Ibíd., capítulo XXV, p. 143.

${ }^{166}$ Ibíd., capítulo XXV, p. 144 . Véase lo que se establecía para evitar los conflictos entre los vecinos a la hora de compartir el agua (pp. 144-145).

${ }^{167}$ Ibíd., capítulo XXV, pp. 145-146.

${ }^{168}$ Ibíd., capítulo XXV, pp. 146-147.

${ }^{169}$ Ibíd., capítulo XXV, pp. 147-148. Véase el capítulo XXVI, pp. 150-154, relativo a los 
Dejando a un lado las ordenanzas, hay que referir, por su carácter local un bando de 22 de agosto de 1770 que establecía las reglas que debían observarse en las fuentes de Madrid para que sus vecinos pudiesen disfrutar libremente de sus aguas $^{170}$. En particular, se regulaba el uso de dichas fuentes y se determinaba el orden y los turnos entre los vecinos y entre éstos y los aguadores cuando acudían a buscar agua, teniendo siempre aquéllos preferencia, pero nada se decía en cuanto a la limpieza ${ }^{171}$.

maestros de fontanería. Se detallan los materiales que debían emplear, la forma de realizar su trabajo y su obligación de inspeccionar y velar por el mantenimiento de las fuentes públicas. Además les correspondía conceder autorizaciones a particulares antes de hacer cañerías y garantizar el servicio de agua.

${ }^{170}$ Ibíd., III,19,1, nota 3. Se trata de una nota a una Resolución de Felipe IV, de 6 de junio de 1659, sobre el cuidado de la limpieza y empedrado de Madrid a cargo de su corregidor con subordinación al Consejo. Ya se recogía en "Nueva Recopilación", III,5, aut. 13. La nota 2 a la misma disposición reproduce el bando de 16 de septiembre de 1800 , que seguía a otros publicados desde 1765, donde se establecían una serie de reglas para los vecinos de Madrid para el saneamiento de sus calles con evidente repercusión medioambiental. Así, cada vecino tenía que barrer diariamente su zaguán y puerta de la calle y tirar la basura en el basurero donde nunca debía depositar aguas sucias ni humedad porque con el "calor aumentan la corrupción". Si incumplía, la pena era de cuatro ducados. Se señalaba un día para la limpieza general de la calle en el que se debía regar y barrer toda la acera, sin perjuicio de hacerlo cualquier otro día que fuese necesario (aquí la multa era de seis ducados). Además, se reglamentaba con detalle la recogida de basuras y escombros. Quedaba prohibido arrojar a la calle, entre otras cosas, aguas sucias o limpias bajo multa de cuatro ducados. Asimismo, se prescribía la obligación de cambiar con mucha frecuencia las aguas para el remojo del bacalao (que nunca se verterían a la calle) para evitar malos olores que pudieran ser tan incómodos como nocivos para la salud. El que hiciese sus necesidades en la calle era castigado con una pena privativa de libertad de seis días de cárcel y si el autor fuese un menor de edad responderían sus padres o tutores. El importe de las multas se destinaba al saneamiento y correspondía velar por el cumplimiento de estas disposiciones, entre otros, al Visitador general de policía, a su Teniente o a los Alcaldes de barrio.

${ }^{171}$ Aunque nos ceñimos a la Edad Moderna, creemos oportuno señalar que, a finales del siglo XIX, las cuestiones relativas a la limpieza de los ríos, fuentes y al sistema de alcantarillado, con evidente contenido medioambiental, seguirían siendo objeto de las ordenanzas municipales. Así, las "Ordenanzas Municipales de la Villa de Madrid", de 16 de abril de 1892, tenían un capítulo concreto dedicado al alcantarillado (título IV, capítulo único). Se prohibía cualquier obra sin licencia que pudiera afectar a su limpieza (artículo 167). En las calles donde no había alcantarilla, cada edificio dispondría de un pozo negro debidamente impermeabilizado para materias fecales que quedaría cegado en el momento en el que se construyese aquélla y se hicieran las oportunas acometidas (artículo 169). Asimismo, toda nueva construcción en una calle donde ya existiese alcantarilla debía tener acometida para las aguas sucias y pluviales (artículo 173) y no se permitían los vertidos en las mismas que resultasen perjudiciales (artículo 174). Quedaba expresamente prohibido arrojar a las alcantarillas basura, excrementos de animales, despojos de pescado o carne, animales muertos o cualquier objeto que interrumpiese el paso de las sustancias fecales (artículo 175). Toda alcantarilla o pozo debía estar a una distancia mínima de 150 metros de un depósito, cañería o conducto de agua limpia, así como de medianerías o propiedades vecinas (artículo 170). Con el fin de garantizar la salud pública, cuando un pozo de aguas sucias quedase cegado, previamente, se limpiaba y desinfectaba (artículo 171), adoptándose una serie de precauciones a la hora de realizar estas tareas para evitar accidentes laborales (artículo 172). Para asegurar la higiene subterránea, las alcantarillas viejas y sin servicio debían quedar inutilizadas (artículo 176). Los gastos de construcción, conservación y limpieza eran a cuenta de los propietarios (artículo 177). Véase el artículo 179 sobre las prescripciones 
para la construcción de las acometidas. Interesante resulta el artículo 183 relativo a las precauciones que había que tomar en relación con las acometidas de las fábricas, sobre todo respecto a los residuos que por su elevada temperatura o por las sustancias que contenían podían repercutir en la salud pública; sin perjuicio de que hubiera que adoptar medidas especiales con determinadas industrias, según el artículo 184. Estas ordenanzas de 1892 también regulaban el aprovechamiento y la distribución de las aguas del río Manzanares, y los baños y lavaderos de sus dos riberas. Se prohibía lavar en las riberas las lanas y ropas inmundas y de color, permitiéndose esta actividad sólo "en el sitio donde estuvo el puente llamado de Santa Isabel" (título V, capítulo XVII, artículo 510). Los daños ocasionados en las conducciones de agua por las crecidas del río serían reparados en tres días (si fuese posible) por los dueños de los lavaderos (título V, capítulo XVII, artículo 511). Se fijaba un día concreto para la limpieza de los referidos lavaderos y ésta no podía realizarse en otro momento (título V, capítulo XVII, artículo 514), distinguiéndose entre los lavaderos situados en la población y los ubicados en el río Manzanares (título V, capítulo XVIII, artículo 518). Los primeros tenían que desaguar y limpiar sus pilas todas las noches por medio de tuberías que acometían a las alcantarillas generales (título $\mathrm{V}$, capítulo XVIII, artículo 525). En cuanto a los requisitos para la construcción de estos lavaderos y las licencias, véase título V, capítulo XVIII, arts. 519-524. Existían pilas especialmente destinadas a lavar las ropas de los enfermos contagiosos (título V, capítulo XVIII, artículo 526). Los dueños de los lavaderos debían conservar siempre sus dependencias, pilas y cañerías en el mejor estado de servicio (título V, capítulo XVIII, artículo 529). No se permitía lavar ropas en los charcos y arroyos de las afueras de la población, así como en los sobrantes de las aguas de depósitos particulares, debiendo hacerse en los sitios autorizados (título V, capítulo XVIII, artículo 530). Los lavaderos de propiedad particular establecidos en el río Manzanares podían usar sus aguas para el lavado de ropa, siempre que no perjudicasen ni a las posesiones contiguas ni a la ribera opuesta (título V, capítulo XVIII, artículo 532). En torno a los requisitos y autorizaciones para estos lavaderos, cfr. título V, capítulo XVIII, arts. 533-535. La limpieza de la ropa se hacía en las caceras establecidas en las riberas y nunca en los márgenes del río (título V, capítulo XVIII, artículo 536). Había sitios específicos para lavar la ropa de los hospitales y de los establecimientos de beneficencia y de la tropa de la guarnición (siempre en los últimos lavaderos y detrás del último destinado al vecindario) (título V, capítulo XVIII, artículo 541). Las pilas cubiertas destinadas al lavado los días de lluvia o cuando el agua del río estuviese sucia, construidas con la oportuna licencia, tenían que desaguarse y limpiarse cada noche en las caceras de las riberas sin afectar a los lavaderos inferiores (título V, capítulo XVIII, arts. 542 y 543), debiendo hacerse una arqueta para no ensuciar las aguas de la ribera (título V, capítulo XVIII, artículo 544). Del mismo modo, se reglamentaba la construcción de los baños en el interior, ensanche o extrarradio y en el Manzanares (título V, capítulo XIX, artículo 552). Los primeros debían reunir las precisas condiciones sanitarias y de ventilación, estar alimentados de las aguas del canal de Lozoya y tener desagües directos por medio de tuberías cerradas a las alcantarillas de servicio público o desagües naturales, no pudiendo ser empleadas las aguas sobrantes del riego (título V, capítulo XIX, arts. 555 y 565). Correspondía a la autoridad local realizar las visitas de inspección y adoptar las medidas que estimase oportunas para mantener las condiciones higiénicas (título V, capítulo XIX, artículo 558). En cuanto a los baños situados en el río Manzanares, se recogían los requisitos para su construcción de forma que se garantizase su limpieza (título V, capítulo XIX, arts. 567-577 y 580-583). Se tenían que limpiar a primeras horas de la mañana o al mediodía si fuese necesario, procurando no molestar ni perjudicar a los baños contiguos con las aguas procedentes de esta operación (título V, capítulo XIX, artículo 579). No se permitía que los tintoreros, latoneros, pellejeros, etc., lavasen objetos de sus oficios o industrias en la parte superior del río, donde existiesen baños, debiendo hacerlo, como dijimos antes, en el vado donde estaba el puente de Santa Isabel (título V, capítulo XIX, artículo 588). Se puede consultar también el título II, capítulo XII, artículo 47 sobre las fuentes públicas y aguadores y, en el mismo título, el capítulo XIII, artículo 55 sobre abrevaderos; así como el 


\section{Derecho general: "Nueva” y "Novísima Recopilación”"172}

Por lo que respecta al Derecho general, el "Ordenamiento de Montalvo" de 1484 recogía una disposición relacionada de manera conjunta con las aguas (referidas como "fuentes y pilas") y las minas, donde se especificaba que pertenecían al rey, así como sus rentas, salvo casos excepcionales de privilegios reales o adquisiciones por prescripción ${ }^{173}$; es decir, a no ser que existiese una concesión

título $\mathrm{V}$, relativo a la salubridad, comodidad e higiene (capítulo I, medidas generales de higiene y sanidad; capítulo VIII, establecimientos insalubres, incómodos y peligrosos; capítulo XV, mataderos, desolladeros y aprovechamiento de despojos de animales —en concreto el artículo 475 disponía que los animales muertos de enfermedades infecciosas fuesen quemados tomando las precauciones necesarias para evitar peligros a los operarios-; capítulo XVI, artículo 499, en relación a los depósitos provisionales de estiércol en los establos de vacas y cabras y capítulo XXI, arts. 601, 603 y 613, respecto a cadáveres, enterramientos y exhumaciones). De la misma fecha y menor entidad jurídica, son las "Ordenanzas municipales de Policía urbana y rural para la villa de Vélez-Blanco" (Almería) y su término. En concreto, la sección segunda del capítulo tercero se dedicaba a la limpieza de las aguas públicas. Se prohibía desviar agua de las fuentes públicas (artículo 112) y llevar a las mismas caballerías o ganados, sobre todo si padecían enfermedad contagiosa, así como lavar en ellas ropas, legumbres u otros objetos o tirar inmundicias (artículo 114). En el artículo anterior se enumeraban los abrevaderos a los que se podía llevar el ganado. Por otra parte, las casas debían estar siempre en perfecto estado de limpieza, tanto interior como exteriormente, como medio para garantizar la salud pública (artículo 116). Además, tenían que estar provistas, en la medida de lo posible, de las cañerías, cubetas y sumideros necesarios para desaguar las aguas sucias y las sobrantes de los usos domésticos, debiendo dichos conductos desinfectarse con frecuencia (artículo 117). Véase el artículo 118 en relación a las condiciones de los estercoleros, el artículo 120 relativo a la ventilación de los retretes para evitar malos olores y los arts. 124 a 130 sobre los cementerios y las inhumaciones.

${ }^{172}$ De la "Nueva Recopilación" hemos consultado, entre otras, la edición de Alcalá de Henares de 1569 y de la Novísima la edición facsímil del Boletín oficial del Estado, Madrid, 1976; 2a edición, 1993.

173 “Ordenanzas Reales de Castilla”, VI,1,8. Esta disposición tenía su origen en una ley de Alfonso VII, de las Cortes de Nájera de 1138, que se reproducía en el "Ordenamiento de Alcalá", XXXII,48. El mismo criterio se seguía en la "Nueva Recopilación", VI,13,2, recogiéndose dos leyes del "Ordenamiento de Alcalá", XXXII,47 (referida a las minas) y 48 que acabamos de citar (relativa a las aguas). Sobre la razón de refundir ambas leyes en una sola, se pronuncia Alejandro Vergara Blanco insinuando que podría deberse a una confirmación de la similitud de ambas materias y a la consideración de las minas y de las aguas como regalías de la Corona, es decir, las dos tendrían la misma naturaleza jurídica. Afirma que "a estas alturas, la dominicalización pública no solo es un hecho asentado, sino que es algo que los Reyes siempre lo han considerado así, desde el inicio de las leyes castellanas" y, por este motivo, al refundir las normas lo único que se hace es "confirmar una realidad jurídica antigua, por la vía de mejorar la técnica legislativa" [Vergara Blanco, Alejandro, cit. (n. 20), I, pp. 49 y 85-86]. Véase Ibíd., IX,18,1, donde se insiste en que las aguas pertenecen al rey y se obliga a los particulares a tener licencia o autorización real para el aprovechamiento de las mismas. Según Vergara, se "acentúa la calidad real del 'derecho' en las aguas" y la "prohibición de labrarlas sin real licencia" y se ratifica "el principio de las aguas como regalía del rey", presente en todo nuestro Derecho histórico desde el siglo XI, es decir, una "concepción dominical pública de todas las aguas susceptibles de aprovechamientos particulares" y, además, se establecía un procedimiento o sistema concesional ya que se exigía para el aprovechamiento un "privilegio" o "concesión" del rey y el previo pago de rentas (lo cual se recogía ya en las Cortes de Nájera) (pp. 50-51 y 89). 
previa o un privilegio nadie podía aprovechar las aguas ${ }^{174}$. Sin embargo, nada se decía en cuanto a su contaminación o limpieza. Una pragmática, promulgada en Valladolid en 1492, insistía en la idea de que las aguas solo se podían utilizar si se pagaban las rentas ${ }^{175}$.

No descubrimos ninguna disposición relacionada con las aguas o con su contaminación en las "Leyes de Toro" de 1505.

Por el contrario, en la "Nueva Recopilación” y, posteriormente, en la Novísima sí se recogían normas dirigidas a la necesidad de cuidar las aguas, imponiendo severas penas al respecto. Enrique III, en el capítulo 30 del "Ordenamiento de Penas de Cámara” de 1400, estableció la prohibición, tanto para los Concejos como para cualquier particular, de cerrar o entorpecer los canales y ríos que entraban en las ciudades por los que circulaban navíos y pescadores y destinarlos a otros fines. La sanción era el pago de una multa de seiscientos maravedís para la Cámara y devolver la situación a su estado inicial, a costa del condenado, en el plazo de treinta días a contar desde el momento en que se interpuso la denuncia ${ }^{176}$.

Una pragmática de Carlos I y Felipe II, dictada en Madrid el 11 de marzo de 1552, prohibía, con carácter general, que cualquier persona, con independencia de su "estado" y "condición", realizase una serie de vertidos en los ríos que ocasionara la muerte de los peces o les provocara algún daño o perjuicio disminuyendo la especie. Se trata, por tanto, de una norma de evidente contenido medioambiental en la que no solo se pretendía proteger los ríos y sus aguas, sino también la propia fauna, en concreto la riqueza piscícola. Se efectuaba un listado de dichos vertidos: cal viva, veneno, beleños, torvisco, gordolobo y, en general, cualquier cosa ponzoñosa o sustancia venenosa con la que se matase el pescado, es decir, cualquier elemento contaminante. Se sancionaba el incumplimiento de esta disposición con una multa de dos mil maravedís, cada vez que se hiciera, y

En cuanto a las regalías en relación a las aguas en el Derecho medieval español, que inspira la legislación posterior. Véanse pp. 45-84.

${ }^{174}$ Vergara Blanco, Alejandro, cit. (n. 20), I, p. 86.

175 “Nueva Recopilación”, VII,7,2. Concluye Vergara que si las aguas pertenecen a los Reyes y nadie las puede utilizar sin privilegio o sin pagar las rentas, "el vínculo jurídico de los particulares con las mismas es subsidiario de tal dominio real, y dirigido, por tanto, solo a su uso" [Vergara Blanco, Alejandro, cit. (n. 20), I, p. 87].

176 “Nueva Recopilación”, VII,10,2 y Ibíd., VII,26,7. Se trata de una disposición similar a la contenida en Fuero Juzgo, VIII,4,29. Véase también Fuero Real, IV,6,6. Este ordenamiento de Enrique III fue recogido, anteriormente, por Alonso Díaz de Montalvo en las "Ordenanzas Reales de Castilla”, VIII,19,33. Señala Porras Arboledas, que la sanción inicial de seiscientos maravedís sería reducida a cien por el propio Enrique III, en la ley 29 del Cuaderno original para el arrendamiento de las penas de Cámara en el Obispado de Cartagena y Reino de Murcia en el bienio 1400-1401, fechado en Valladolid, el 18 de mayo de 1401, al que considera más elaborado [Porras Arboledas, Pedro Andrés, El Ordenamiento de Penas de Cámara de Enrique III (1400). Un nuevo manuscrito, en Cuadernos de Historia del Derecho, 10 (2003), pp. 209-234, en p. 215]. Esta sanción de cien maravedís será la que se mantenga en las "Ordenanzas Reales". No obstante, en la versión que hemos manejado de la Novísima Recopilación se contiene la pena de seiscientos maravedís, aunque la transcripción del texto coincide más con la ley 29 de 1401 y con el "Ordenamiento de Montalvo", que con la ley 30 de 1400 (según la reproducción que hace de estas normas Porras Arboledas, en p. 227). 
con el destierro de la ciudad, villa o localidad durante seis meses. El importe de la multa se destinaba en partes iguales para el denunciante, para el juez que dictaba la sentencia y para la Corona ${ }^{177}$.

En la misma Pragmática, confirmada por Felipe II en Toledo en 1560, hay otra norma sobre la pesca, dirigida de forma más específica a la conservación de la especie. Se prohibía pescar en época de cría o utilizando instrumentos especialmente dañosos (paños de "xerga”, lienzos, sábanas o cestos). Se sancionaba con quinientos maravedís y con la confiscación de lo pescado y de los elementos utilizados, elevándose la multa a mil maravedís e imponiéndose una pena privativa de libertad de ocho días cuando se pescaba con jurdía o se hacían "paradas" o “corrales”. Asimismo, quedaba expresamente prohibido desviar el río de su cauce o reducir éste para secarlo y coger los peces o hacer pozos o pescar, como decíamos, en tiempo de cría o desove, siendo, en este caso, la pena de dos mil maravedís y seis meses de destierro del lugar donde fuera vecino el autor. Las multas se repartirían en la forma establecida en la disposición anterior. Además, en aras a la seguridad jurídica, se conminaba a que cada Concejo y provincia dictase ordenanzas donde se especificase con qué redes se podía pescar, estableciendo el marco necesario según las características del pescado de cada río para evitar la extinción de la especie. También se debía declarar la época de cría y desove de los peces. Para redactar dichas ordenanzas se tenían que nombrar personas expertas, debiendo guardarse el marco de la red en el arca del Concejo para poder comprobar cuándo se había incumplido la norma ${ }^{178}$.

En las nuevas ordenanzas de minas, aprobadas por Felipe II, por Pragmática de 18 de marzo de 1563, se establecía que el agua que se utilizaba para lavar los metales extraídos de dichas minas debía ser sacada de los ríos o estanques y no volver a ellos. Si esto no era posible se tenían que colocar setos para evitar los perjuicios que se podían ocasionar a los pueblos o ganados. Suponemos que una de las razones sería el carácter altamente contaminante de los referidos metales y su repercusión en la salud pública ${ }^{179}$. Con la misma finalidad, en las "Nuevas Ordenanzas que se han de guardar en el descubrimiento labor y beneficio de las minas de oro y plata, azogue y otros metales", también de Felipe II, de 22 de agosto de 1584, y que derogaban las anteriores, se prohibía el desagüe de los lavaderos de las minas a los ríos, arroyos o estanques, correspondiendo a la Justicia de la mina en cuyo distrito se hiciera dicho lavadero controlar el cumplimiento de lo dispuesto $^{180}$.

177 “Nueva Recopilación”, VII,8,9 y Ibíd., VII,30,8. Según Vergara Blanco, esta pragmática, junto con otras posteriores, sería una manifestación de la calidad "pública" de los ríos y de la intervención de la administración en materia de aguas [VERGARA BlANCO, Alejandro, cit. (n. 20), I, p. 87].

178 "Nueva Recopilación", VII,8,10 y Ibíd., VII,30,9. Felipe II, en las Cortes de Madrid de 1586, confirmaría lo dispuesto por Juan II, en Toro en 1409, sobre la prohibición de salar el pescado con agua de mar so pena de perderlo ("Nueva Recopilación”, VII,8, 11 y 14 y Ibíd., VII,30,10).

179 "Nueva Recopilación”, VI,13,5.

180 "Nueva Recopilación”, VI,13,9 y Ibíd., IX,18,4, \$47. Indica Jordano Fraga (aunque confunde el título de la Novísima Recopilación señalando el 17, en lugar del 18) que "se reconoce 
Con el fin de aprovechar la riqueza maderera, Fernando VI promulgó las “Ordenanzas de Montes de Marina”, el 31 de enero de 1748, en las que se disponía que todos los montes del territorio quedasen sujetos a la jurisdicción de Marina que organizaba y controlaba su explotación, con graves repercusiones medioambientales en las que no vamos a entrar por no contener referencia alguna a las aguas ${ }^{181}$.

la existencia de intereses que exigen la intervención de los poderes públicos, sustrayéndose el conflicto del ámbito privado e imponiéndose medidas tendentes a la evitación de los perjuicios que, incluso más tarde en la ordenanza, se concretan en la forma de fijación de de las medidas que han de tener los lavaderos". Llega a insinuar que podríamos estar "ante la primera formulación rudimentaria en materia preambiental del principio quien contamina paga" [JORDANO Fraga, Jesús, cit. (n. 2), p. 30]. Cfr. Viguri Perea, Agustín, Globalización y defensa del medio ambiente en el derecho privado: aplicación del principio "quien contamina paga" y régimen de la responsabilidad civil objetiva: derecho español, europeo, norteamericano y japonés (Madrid, Colegio de Registradores de la Propiedad y Mercantiles de España, 2009).

${ }^{181}$ Véase Ibíd., VII,24,22 donde se contiene la ordenanza para la conservación y aumento de los montes de Marina en las provincias y distritos que se expresan. Las penas por el incumplimiento de esta ordenanza se recogían en la Real Orden de 12 de diciembre de 1748. Para muchos, esta norma fue la causa principal del fin del Común de Segura y su tierra, al que antes nos referíamos, ya que acabó con los aprovechamientos forestales de sus vecinos, mermó la ganadería y asoló gran parte de los bosques de la Sierra, al constituirse una entidad administrativa sin precedentes que perduraría hasta 1812. Lo mismo sucedería en muchas otras zonas. Según Jaquenod, las "Ordenanzas de Montes de Marina" encajan a la perfección "con la mentalidad despótico ilustrada de la época, distorsiona el mercado y elimina el libre tráfico de madera”. En ellas "se atiende puntualmente al tratamiento cuidadoso y prolijo de viveros y árboles, como asimismo a la limpieza, orden y beneficio en diferentes grados de protección materialista", siendo el objetivo de estas actuaciones aumentar la producción para que nunca faltase leña a herrerías y fábricas de artillería. Es más, insiste en que "el espíritu de estas ordenanzas, lejos de llevar intrínseca la explotación racional de los recursos, esquilma sin escrúpulos a los mismos, vertebrándose la idea central en la producción, la venta y el desmedido lucro", convirtiéndose en "un paradigma de gestión y tratamiento totalmente adverso a la naturaleza, que ignora sus leyes y desconoce toda regla de explotación conservacionista", pretendiendo que quedase garantizado el suministro de madera para el abastecimiento de los astilleros, estableciéndose una "auténtica empresa mercantil pública monopolizadora del comercio de la madera". En definitiva, estas ordenanzas tendrían efectos desastrosos en los montes y plantíos y, en general, en el medio ambiente, ya que se rompía "el régimen jurídico tradicional de relación entre el montañés y los montes" y "la Administración y Jurisdicción se encargan a funcionarios de la Administración Central, que no conocen la realidad, al punto que ignoran la época en la que la madera debe cortarse" [JAQUENOD MarTíneZ, Silvia Susana, cit. (n. 10), pp. 84-85 y 8687]. Indica Jordano Fraga que en la Edad Moderna se hizo necesaria una actividad legislativa para hacer frente a "las necesidades planteadas por la destrucción a gran escala de los recursos forestales como consecuencia de su consumo masivo", lo que permitiría la aparición de una amplia normativa que consideraba "lo forestal" más allá de las relaciones de propiedad, dando lugar al nacimiento en el Estado moderno del "Derecho de los recursos naturales" [JORDANO FraGA, Jesús, cit. (n. 2), pp. 25-26]. En torno a la legislación de la Edad Moderna dirigida a la conservación y aumento de montes y plantíos entre los siglos XV-XVIII, véase pp. 26-28. Hay que mencionar la pragmática de los Reyes Católicos, de 28 de octubre de 1496, sobre la conservación de los montes y plantíos para el bien común de los pueblos ("Nueva Recopilación", VII,7,7 y Ibíd., VII,24,1); la pragmática de Carlos I y doña Juana, de 21 de mayo de 1518 , relativa a la formación de nuevos plantíos de montes y arboledas, y de ordenanzas para conservar los viejos y nuevos ("Nueva Recopilación”, VII,7,15 y Ibíd., VII,24,2) o la "Real 
Fernando VI, en la "Ordenanza de Intendentes Corregidores", de 13 de octubre de 1749, establecía la Instrucción que debían observar aquéllos para el cumplimiento de las obligaciones de su oficio, reflejándose la intervención de la Administración en materia de aguas. A ellos correspondía nombrar ingenieros cualificados encargados de informar, entre otros asuntos, de los ríos de cada provincia que se podían comunicar y hacer navegables y dónde era factible y resultaba más conveniente abrir nuevas acequias útiles para el regadío; así como en qué estado se encontraban los puentes, cuáles requerían ser reparados o construidos y qué puertos se debían ensanchar, limpiar, asegurar, mejorar o establecer de nuevo. De este modo, cada Intendente conocería el estado de su provincia, la calidad de sus tierras y los medios de mejorarlas ${ }^{182}$. Lo mismo se contenía en la Nueva Instrucción que deben observar los corregidores y alcaldes mayores del Reino, promulgada por Carlos III, por Resolución de 6 de mayo de 1785 y 3 de marzo de 1788 y Cédula de 15 de mayo de 1788. Aquí se indicaba que concernía a "personas inteligentes y prácticas", informar de todos los aspectos anteriores, añadiendo la fabricación de molinos y batanes. El fin era que, a través de los referidos informes y de las noticias que adquiriese por sí mismo, cada corregidor conociera puntualmente el estado de todos los pueblos de su jurisdicción y las medidas que debería adoptar para su conservación y mejora dando conocimiento, en su caso, a sus superiores ${ }^{183}$. En esta disposición también se establecía que competía a los corregidores facilitar el aprovechamiento de las aguas para garantizar la fertilidad de los campos, permitiendo que se sacasen acequias de los ríos, "sangrándolos" por la parte más conveniente, de forma que no se perjudicase su curso y los términos y distritos inferiores. Asimismo, se descubrirían las subterráneas para su uso ${ }^{184}$. Según los capítulos 28, 29 y 31 de la "Ordenanza de Intendentes Corregidores" de 1749 y los capítulos 51, 52 y 53 de la "Instrucción de Corregidores" de 1788, era facultad de los intendentes corregidores velar porque todas las Justicias de su provincia y sus subdelegados mantuviesen en buen estado los caminos públicos y puentes y que justificasen ante el Consejo del Rey cualquier reparación o mejora ${ }^{185}$.

Especial preocupación había por la protección y mantenimiento de las acequias, lo cual incidía directamente en su limpieza e indirectamente en evitar la contaminación. Felipe V promulgó las "Ordenanzas para la conservación de la Real Acequia del Jarama”, el 7 de enero de $1740^{186}$. Se incidía en su utilización,

Ordenanza para el aumento y conservación de montes y plantíos” de 1748 de Fernando VI (Ibíd., VII,24,14). Para Jordano Fraga el motivo fundamental que impulsó esta normativa fue el uso y la aplicación "de los recursos maderables en la construcción naval y para la obtención de energía" pero también "se reconocía la importancia estética de los árboles como elementos del entorno" [Jordano Fraga, Jesús, cit. (n. 2), p. 28].

${ }^{182}$ Novísima Recopilación VII, 11,24, $\$ 20$.

${ }^{183}$ Ibíd., VII, 11,27, $\$ 45$.

${ }^{184}$ Ibíd., VII, 11,27, \$48.

${ }^{185}$ Ibíd., VII,35,5.

${ }^{186}$ De la misma se contienen en la Novísima Recopilación algunos parágrafos relacionados, sobre todo, con cuestiones jurisdiccionales, de gobierno y de competencia y que recogemos a título de ejemplo. Véase respecto a estas ordenanzas, MARTínez Ruiz, Enrique y DE PAZZIS PI Corrales, Magdalena, Protección y seguridad en los sitios reales desde la Ilustración al Liberalismo 
preservación y gobierno. En virtud de esta disposición, dicha Acequia, su riego y todos los derechos relacionados con su uso quedaban incorporados a la Corona, de modo que correspondería a ésta no solo el disfrute de los mismos, sino también su mantenimiento y mejora, incurriendo en pena cualquiera que incumpliese las ordenanzas con independencia de su estado o condición ${ }^{187}$. Así, para el régimen y conservación, recolección de productos del riego y administración de las tierras, el monarca nombraría un gobernador de la Real Acequia ${ }^{188}$, el cual debía velar por el cumplimiento de las ordenanzas, exigiendo a los transgresores las multas impuestas y obligando a sus subordinados a que le diesen cuenta de todo cuanto sucediera en relación a las mismas. Dicho gobernador tendría competencia exclusiva en esta materia, de la que quedaban al margen otros Tribunales, aunque sus sentencias podían ser recurridas ante la Real Junta de Obras y Bosques, siendo inapelables las decisiones referentes a las penas previstas en las ordenanzas sin que se pusiera en conocimiento del monarca a través del secretario de Estado ${ }^{189}$. Además, el gobernador era juez privativo en todas las causas relativas a los empleados de la Real Acequia y a los hacendados de las acequias particulares respecto a riegos, desórdenes y cualquier otro asunto y la sentencia era igualmente apelable sólo ante la Real Junta de Obras y Bosques, en los mismos términos antes señalados ${ }^{190}$. En cualquier caso, todo el que utilizase la Real Acequia y su riego o llevase a cabo una actividad prevista en la ordenanza, dirigida a la conservación, perfección, aumento o mejor uso de la misma, estaba sujeto a las órdenes y jurisdicción del Gobernador en lo que directa o indirectamente tuviese que ver con la Acequia, con el riego o con la administración y cobro de derechos, debiendo éste mantenerse informado de cualquier acontecimiento. Se declaraba que el Gobernador era competente en los aspectos económicos, directivos y gubernativos no comprendidos en las ordenanzas, pudiendo dictar y ejecutar toda providencia que creyese útil, previo informe y dictamen del Contador Fiscal, dando cuenta al monarca de lo que hubiese providenciado y ejecutado. Si alguna de estas providencias resultase perjudicial para la Real Acequia o su riego, para la Hacienda Real o para terceros, se debía consultar al Rey antes de su ejecución, y se esperaría a la resolución real, salvo que la dilación pudiera ocasionar algún daño o perjuicio grave, ya que, en tal caso, primero se ejecutaban las providencias, tras informar al contador fiscal del riesgo y luego, se informaba al monarca. Lo mismo se establecía respecto a la ejecución de lo previsto en las ordenanzas en cuanto a las alteraciones o modificaciones, debiendo consultarse al Rey en materias graves si la dilación no causaba perjuicios. En todas las cuestiones económicas, gubernativas y directivas, el Gobernador no

(Publicaciones Universidad de Alicante, Alicante, 2010), p. 73. El proyecto de canalización del río Jarama mediante presas y acequias, altamente tecnificado, entraba dentro de las propuestas de mejora de Madrid y, en concreto, afectaba directamente a los palacios reales. Los beneficios se repartían entre el rey y las tierras implicadas (p. 41).

${ }^{187}$ Novísima Recopilación, III, 10, 7. En definitiva se recoge su incorporación a la Corona y las facultades y privativa jurisdicción de su Gobernador en todo lo relacionado con su conservación y mejora.

${ }^{188}$ Ibíd., III, 10,7, $\$ 34$.

${ }^{189}$ Ibíd., III, 10,7, \$46.

${ }^{190}$ Ibíd., III, 10,7, \$49. 
estaba sujeto a la Junta de Obras y Bosques ni estaba obligado a preguntar a la misma, sino solo al Rey a través del Secretario de Despacho Universal de Estado. La Junta solo tenía jurisdicción en el conocimiento de las apelaciones frente a los pleitos y causas contenciosas sustanciadas por el Gobernador ${ }^{191}$.

Todos los asuntos relativos a la Real Acequia de Alcira se declaraban competencia privativa de los Intendentes de Valencia, en virtud de una Real Orden de Carlos III, de 24 de julio de 1764, correspondiendo conocer de las apelaciones al Consejo de Hacienda ${ }^{192}$.

Una Real Cédula de Carlos III, de 17 de febrero de 1771, incorporaba la Acequia de la Vega de Colmenar de Oreja a la Corona, bajo la jurisdicción y las "Ordenanzas de la Acequia del Jarama" y la subordinación a su Gobernador, obligando a hacer las obras y reparaciones necesarias para su mejora que, a partir de ese momento, serían a cargo de la Hacienda Real. Asimismo, se pondrían cuadrilleros para su protección y la de sus frutos y todos los hacendados de la Vega estaban compelidos a hacer y mantener las caceras o canales particulares que conducían el agua para regar, cobrándose los mismos derechos de riego que en la Acequia del Jarama ${ }^{193}$.

Las Ordenanzas de 31 de mayo de 1792 del Real Sitio de Aranjuez, promulgadas por Carlos IV, determinaban las facultades del superintendente general del Real Sitio de Aranjuez y de las Acequias de Colmenar y Jarama incorporadas, desde ese momento, a su gobierno ${ }^{194}$. Estas ordenanzas recogían con detalle las atribuciones del gobernador de Aranjuez y de su Teniente. En concreto, se indicaba que el gobernador tenía jurisdicción en todo lo relativo a la conservación, administración y recaudación de las acequias de Colmenar y Jarama, añadidas a su gobierno, procediendo del mismo modo en que lo hacían los anteriores Gobernadores de las mismas y observando las ordenanzas y órdenes posteriores ${ }^{195}$. Cuando en un proceso penal, con ocasión de un delito de caza o pesca, la denuncia se hubiese interpuesto ante el Gobernador, el Teniente intervendría como asesor, pero si se hubiera presentado ante él mismo, procedería “como tal”, consultando al Rey en

\footnotetext{
${ }^{191}$ Ibíd., III, 10,7, $\$ 79$.

${ }^{192}$ Ibíd., VI,10,9.

${ }^{193}$ Ibíd., III, 10,8. Con esta disposición se resolverían gran parte de los conflictos que se ocasionaban en relación a la recolección de los productos de regadío pertenecientes a la Corona o a la regulación de los riegos entre los dependientes reales y los hacendados y propietarios de las acequias particulares, respecto a los "tiempos y formas de utilización del agua", así como los problemas relativos a los gastos ocasionados por las obras de reparación. $\mathrm{Al}$ incorporar esta acequia a la Corona y vincularla a la del Jarama se determinó que correspondía a "la Real Hacienda el sostén, mejora y vigilancia de dicha acequia, así como la protección de los frutos de las tierras que regaba, costos que cubriría con la ratificación de los derechos de riego que venían cobrándose a los usuarios del agua de la acequia, mientras que a los dueños de tierras en la vega corresponderían los gastos de mantenimiento de las caceras particulares" [MARTíNEZ Ruiz, Enrique - De Pazzis Pi Corrales, Magdalena, cit. (n. 185), pp. 78-79]. Las caceras son canales por donde se conduce el agua para el riego.

${ }^{194}$ Ibíd., III,10,9.

${ }^{195}$ Ibíd., III,10,10, \$2. En cuanto a las facultades del Teniente del Gobernador de Aranjuez, véase Ibíd., III,10,11.
} 
ambos casos, y respetando las ordenanzas de caza y pesca ${ }^{196}$. Especial celo se debía tener si el denunciado por delito de caza o pesca se trataba, precisamente, de un guarda o alguien cuya función era evitarlo. En este caso, el Teniente obligaba a que el denunciante entregase personalmente la denuncia firmada al Fiscal con sus correspondientes pruebas. El Fiscal actuaría con "sigilo" procurando que el denunciado fuese "cogido con el cuerpo del delito", para detenerlo y suspenderlo en su oficio, dando cuenta al Rey, a través del gobernador, y al superior jerárquico del Guarda ${ }^{197}$.

Una Real Orden de Carlos IV, de 2 de julio de 1795, declaraba la libertad de navegación en el río Nalón, en Asturias, bajo la observancia de una serie de reglas. Así, se establecía el libre derecho tanto a pescar como a navegar y, en consecuencia, la facultad privativa de pescar en un sitio concreto solo podría derivar de privilegio real o posesión inmemorial, siempre que no se entorpeciera la libre navegación de los ríos ni el derecho de pesca de terceros fuera del lugar privilegiado $^{198}$. Del mismo modo, no se permitía atravesar los ríos con estacadas que cortasen el paso o impidiesen la subida de salmones y otros peces, privando del derecho a pescar a los pueblos riberiegos situados en la parte superior del río ${ }^{199}$. Por este motivo, cualquier estacada que atravesase el río (en su totalidad o alguno de sus brazos) sería retirada por ser contraria tanto a la naturaleza del privilegio en que se fundaba como al derecho público general de pesca y navegación, quedando siempre a salvo la facultad de los titulares de los referidos privilegios a pescar en los sitios indicados en los mismos con redes $\mathrm{u}$ otros medios, siempre que fuesen compatibles con la libre navegación y pesca en el resto del río ${ }^{200}$. Lo anterior no era aplicable a las construcciones realizadas sobre el borde del río para la pesca particular de lampreas que debían mantenerse al no estorbar el libre paso de los barcos ni la subida de la pesca. También se respetaría el derecho que tenían algunos particulares a realizar y conservar dichas construcciones en determinados lugares y el derecho de los pescadores a construirlas temporalmente en la época de la pesca,

${ }^{196}$ Ibíd., III, 10,11, \$32.

${ }^{197}$ Ibíd., III,10,11, \$33. En relación a las competencias del Intendente de San Ildefonso en materia de delitos de caza y pesca, Véase la Real Cédula de Carlos III, de 6 de diciembre de 1774, por la que se promulga la "Ordenanza del Real Bosque de Valsaín” y la jurisdicción del intendente y asesor de San Ildefonso para el conocimiento de causas (Ibíd., III,10,13, $\$ \$ 24,28,29,37)$. Aquí la caza y la pesca estaban reservadas al entretenimiento real aunque las Justicias de los pueblos solían tolerar que los vecinos cazaran o pescaran usando medios ilícitos. Para implicar a estas autoridades en el respeto de las ordenanzas se les daban competencias en la persecución de estos delincuentes y en el control del uso de determinadas armas y aparejos que quedaban expresamente prohibidos [Martínez Ruiz, Enrique - De Pazzis Pi Corrales, Magdalena, cit. (n. 185), p. 78]. La pena solía ser pecuniaria o de destierro y el denunciado estaba en prisión mientras se sustanciaba la causa y, una vez condenado, hasta que pagase la correspondiente multa y entregase los instrumentos no permitidos, no admitiéndose fianza (Novísima Recopilación, III, 10, 13, \$39). En general, en cuanto al Real Sitio de San Ildefonso y la jurisdicción y facultades de su Intendente, consultar la Real Instrucción de Carlos IV de 1795 (Ibíd., III, 10, 14).

${ }^{198}$ Novísima Recopilación, VII, 30,16, \$\$1 y 2.

${ }^{199}$ Ibíd., VII, 30,16, \$3.

${ }^{200}$ Ibíd., VII, 30,16, $\$ 4$. 
quedando siempre reservada la facultad de la autoridad pública de prohibirlas, cuando causasen alguna alteración en la corriente del río, o de establecer la forma de hacerlas que fuese más compatible con la libertad de navegación ${ }^{201}$.

Ya a principios del siglo XIX, tenemos que hacer referencia a la "Ordenanza general sobre caza y pesca”, promulgada por Carlos IV, en virtud de Cédula de 3 de febrero de 1804. En cuanto a la pesca, se prohibía, con carácter general, pescar en aguas dulces, desde el 1 de marzo hasta el 31 de julio de cada año, con cualquier instrumento, a excepción de la caña, y solo podrían pescar, desde el 24 de junio, los propietarios particulares o sus arrendadores en base a la Real Orden de 8 de junio de $1756^{202}$. Se aclaraba que en los informes solicitados por todo el reino

${ }^{201}$ Ibíd., VII, 30,16, \$5.

${ }^{202}$ Ibíd., VII, 30,11, \$15. Hay que referir que, con anterioridad, el "Reglamento de Pesca y Navegación" de 27 de agosto de 1763 hacía una llamada al "ejercicio racional de la pesca" [Jordano Fraga, Jesús, cit. (n. 2), p. 29]. Hemos utilizado la edición del reglamento del Ministerio de Agricultura, Pesca y Alimentación de 1982. Se señalaba la necesidad de someter la pesca a reglas precisas y de controlar los instrumentos, su uso y la época para evitar la destrucción de las crías, la disminución de la especie y los problemas de abastecimiento, afectando a la propia subsistencia del pescador ya que "por lucrar unos por algún tiempo padecen muchos males en todos" (artículos 35 y 36, pp. 36-37). Seguidamente, se enumeraban las principales artes de pesca ("palangre, jábega, boliche, traiña, nansa, solta, batuda y fitora [cítora]") indicándose que cualquier otra debía tener el permiso de las autoridades oportunas (artículo 37, p. 38). El que pescaba con instrumento prohibido sufría pena de cárcel y multa de cincuenta libras, la mitad para el gremio y la otra, para el denunciante si lo hubiere y se quemarían públicamente dichos instrumentos (artículo 38, pp. 38-39). A continuación, se analizaban con detalle las diferentes artes de pesca permitidas. Del palangre se decía que era el más antiguo, el de mayor utilidad para el abasto y menor lucro para el pescador y tenía preferencia para la pesca de la sardina y la anchoa en su temporada, sin perjudicar al sardinal, bajo pena de cuatro libras (artículos 4248, pp. 41-47). También se destacaba la antigüedad de la pesca de arrastre mediante jábega, precisándose la anchura de las mallas para el copo con el fin de prevenir daños, imponiéndose la sanción correspondiente a los instrumentos vedados en caso de incumplimiento (artículos 46-52, pp. 47-51). Lo mismo se indicaba respecto al boliche o jábega más pequeña, que seguía el régimen de la jábega con indicaciones precisas en cuanto a las redes, siendo el castigo de veinticinco libras y la pérdida de los instrumentos de pesca (artículos 53-55, pp. 52-55). Del sardinal se indicaba que era usual todo el año y debía emplearse durante la noche, evitando que la red llegase al fondo, salvo en los meses de octubre, noviembre, diciembre y enero, bajo multa de cuatro libras (artículos 56-57, pp. 55-56). Se especificaban las características de la traína para pescar sardinas, besugos, doradas o lenguados, entre otras especies, de forma que, aunque llegasen al fondo, no afectasen al sustento de los peces (artículo, 58, pp. 56-57). Por su parte, las nansas se podían utilizar todo el año, siempre que no impidiesen la pesca de la sardina y la anchoa en su temporada, rompiendo los sardinales, siendo la pena de seis libras para las nansas mal colocadas aunque no hubiesen llegado a causar daño, indemnizándose éste en su caso (artículos 59-61, pp. 57-60). Asimismo, era usual todo el año la red llamada solta para la pesca de salmonete, caballa o boga (artículos 62-63, pp. 60-61) y las batudas (artículo 64, pp. 61-62), especificándose las medidas de ambas. Por su parte, la cítora se utilizaría de noche con tea (artículo 65, p. 62). Con carácter general, se señalaba que el abastecimiento de los pueblos era el fin primordial de la pesca, de atención preferente, pero debía conciliarse con el beneficio del pescador, respetándose siempre las reglas de policía establecidas (artículo 67, pp. 63-65). El conocimiento de las causas derivadas del uso de artes ilícitas correspondía a la Jurisdicción de Marina (artículo 70, p. 66). Se prohibía cualquier embalo o ruido o el uso de cal que pudiera ahuyentar o matar a los peces, sancionándose con veinticinco libras (artículo 72, p. 68). La 
había uniformidad en señalar que el desove y la cría de la trucha tenían lugar en los meses de octubre, noviembre, diciembre, enero y febrero, prohibiéndose su pesca en dichos meses y tolerándose en el resto ${ }^{203}$. Además, en la época en la que estaba permitida la pesca, solo se podían utilizar el anzuelo, nasas y redes de cualquier género, teniendo cada malla la extensión o cabida que se indicaba mediante una figura en el margen, aprobada por la Justicia. La entrada de la pesca debía ser por la cabeza y no por la cola y, en modo alguno, se usaría otro instrumento y mucho menos medios ilícitos como cal viva, beleño o coca y cualquier otro simple o compuesto que provocase la extinción de la cría de los peces o fuese nocivo para la salud pública o para los abrevaderos de los ganados ${ }^{204}$. Observamos cómo se indicaba de manera expresa que el empleo de estas sustancias podía afectar no solo a la especie piscícola sino también a la salud pública por su carácter contaminante. Por su parte, los menestrales, artesanos, trabajadores y oficiales mecánicos solo estaban autorizados a pescar los días de fiesta de precepto en los que no se trabajase, antes o después de la misa, y siempre que se tratara de la época permitida y usarían la caña los mismos días todo el año ${ }^{205}$. La sanción en caso de incumplimiento de la ordenanza se establecía de forma conjunta para la caza y la pesca. Así, cazar o pescar en época de veda se castigaba con una multa de tres mil maravedís y la suspensión del derecho a cazar (y suponemos, aunque la disposición no lo diga, que a pescar) durante todo un año, cuando se hacía por primera vez, si se trataba de nobles o "personas de honradas", ya que la norma presuponía que este tipo de acciones eran más frecuentes en "personas distinguidas". Dicha pena se duplicaba en caso de reincidencia y, si se volvía a reincidir, la multa se triplicaba y se imponía la prohibición de cazar para siempre, con la confiscación de los medios empleados para ello. Cuando la infracción la cometían plebeyos, la primera vez, la pena era de mil quinientos maravedís y dos años de suspensión o bien treinta días de cárcel sin multa alguna. La segunda vez, se duplicaba tanto la pena pecuniaria como la privativa de libertad y la suspensión se elevaba a seis años y la tercera, se triplicaba la multa y la suspensión era para siempre con la confiscación de los instrumentos correspondientes. En todos los supuestos las cantidades iban destinadas al Juez, al denunciante y a la Real Cámara en partes iguales y el valor de los instrumentos confiscados se atribuía íntegramente a la Corona, manteniéndose en depósito mientras se dictaba la correspondiente providencia ${ }^{206}$. Los corregidores y justicias de cada localidad eran los que tenían competencia para conocer en primera instancia, en su respectiva jurisdicción, de todos los asuntos relacionados con la caza y la pesca, escuchando a las partes, mediante una instrucción breve que no podía exceder de cuatro días, e imponiendo el oportuno castigo a todos los que hubiesen delinquido con independencia de la persona, estado, clase, título, empleo, grado

pesca en domingo o días festivos de noche necesitaba permiso de las autoridades eclesiásticas y conocimiento de las civiles, bajo multa de diez libras y la pérdida del importe de la pesca que se destinaban a fines piadosos (artículo 73, pp. 68-69).

${ }^{203}$ Novísima Recopilación, VII,30,11, \$16

${ }^{204}$ Ibíd., VII,30,11, $\$ 17$.

${ }^{205}$ Ibíd., VII,30,11, \$18.

${ }^{206}$ Ibíd., VII,30,11, \$\$19 y 20. 
militar, político, carácter, dignidad o fuero que tuviesen por privilegio especial, sin que fuese competente en la materia ningún Consejo, Tribunal o Junta, quedando expresamente derogado cualquier fuero privilegiado ${ }^{207}$. Cuando la infracción de las ordenanzas de caza y pesca era cometida por eclesiásticos seculares o regulares, les serían confiscados la escopeta, perros o cualquier otro medio y se procedía a la exacción de la multa y, en caso de resistencia o reincidencia, se realizaba el pertinente informe por parte del corregidor o justicia de la localidad en cuyo territorio tuviese lugar la contravención y se remitía al Consejo del Rey para proveer lo que estimase oportuno para la corrección o enmienda por los medios establecidos por el Derecho ${ }^{208}$. En las apelaciones frente a las sentencias, autos y providencias, se exigía el previo depósito de las multas para el Consejo y su Sala de Justicia a la que privativamente correspondía su conocimiento ${ }^{209}$. El incumplimiento de esta ordenanza quedaba justificado con la simple declaración del guarda, ministro o alguacil jurado, junto con la aprehensión de la escopeta, perro o, en su defecto, cualquier otro instrumento ${ }^{210}$. Se recomendaba a los corregidores que velasen, de forma especial, por el respeto de lo dispuesto en la ordenanza (ya que de su observancia dependería el beneficio público) y que inspeccionasen su aplicación por "las Justicias de los pueblos" de las diferentes provincias, partidos, distritos o jurisdicciones, castigando a los delincuentes, sin que se tolerase contravención por causa alguna. En caso de infracción, se daría cuenta al Consejo del Rey. El control de los corregidores correspondía a los fiscales de las Salas de Crimen de las Chancillerías y Audiencias, debiendo informar a la Sala de Justicia del Consejo ${ }^{211}$. Los corregidores y las Justicias ordinarias tenían que controlar que la ordenanza se publicase los ocho primeros días del mes de febrero de cada año, para su observancia en lo relativo a la veda general de caza y pesca y, respecto a la pesca de la trucha, la publicación se hacía en los ocho primeros días del mes de septiembre. Asimismo, el corregidor debía recoger testimonio de la publicación de las Justicias de su partido y todo incumplimiento podría ocasionar un juicio de residencia e impedir la promoción de los respectivos funcionarios ${ }^{212}$. Quedaba expresamente derogada cualquier disposición anterior sobre la materia ${ }^{213}$.

Carlos III, en la Instrucción de Corregidores, inserta en Cédula de 15 de mayo de 1788, capítulo 57, obligaba a los corregidores y Justicias a velar por el cumplimiento de las ordenanzas de caza y pesca, imponiendo las penas previstas.

${ }^{207}$ Ibíd., VII,30,11, \$21. Una Real Resolución a consultas de 19 de mayo de 1769 y 27 de febrero de 1773 había establecido que el conocimiento de las causas de contravención a las ordenanzas de caza y pesca correspondía de manera privativa a las Justicias ordinarias, excluyendo cualquier fuero privilegiado.

${ }^{208}$ Novísima Recopilación, VII,30,11, \$22.

${ }^{209}$ Ibíd., VII,30,11, \$23.

${ }^{210}$ Ibíd., VII,30,11, \$24.

${ }^{211}$ Ibíd., VII,30,11, \$25.

${ }^{212}$ Ibíd., VII,30,11, \$26.

${ }^{213}$ Había una Cédula de 3 de marzo de 1769 que recogía las reglas sobre la veda de caza y pesca que debían observarse mientras se promulgaba la ordenanza general y que resumía todas las providencias anteriores sobre la materia, desde la Real Provisión de 7 de marzo de 1754. Hubo otra cédula posterior, en el mismo sentido, de 16 de enero de 1772. 
Si en sus respectivos distritos, hubiese zonas de pesca en ríos, puertos o lagos debían encargarse de su conservación y aumento y reparar las que estuviesen deterioradas ${ }^{214}$.

La Novísima Recopilación dedicaba el título cuarenta del libro VII al resguardo de la salud pública y resulta llamativo que en ninguna de las disposiciones se hiciera alusión a la contaminación de las aguas, aunque son varias las normas atinentes a la del aire ${ }^{215}$. No obstante, en la Real Orden, de 6 de enero de 1785, de Carlos III y Cédula del Consejo de 13 de febrero del mismo año, por la que se determinan las Reglas que debían observarse en el Reino de Valencia para evitar la epidemia de tercianas, se concluía que una de las causas de dicha epidemia, aparte de la situación de pobreza y necesidad de los pacientes y del cultivo del arroz fuera de los lugares señalados, eran las aguas estancadas en muchas zonas. Por este motivo, se ordenaba que se diesen limosnas y auxilio a los necesitados y que se diera curso a las aguas estancadas, a costa de los propietarios de los terrenos si tenían capacidad económica para hacerlo y, en caso contrario, repartiendo el importe entre los vecinos, si no había Propios, ya que, en tal supuesto, se acudiría a ellos con carácter preferente correspondiendo a las Justicias y Juntas de Propios la ejecución de los desagües ${ }^{216}$. Una Circular del Consejo de 11 de noviembre de 1785, dictada con motivo de la epidemia de tercianas, adoptaba una serie de medidas para atender a su asistencia y curación; entre ellas, examinar las cañerías de las fuentes para comprobar si había aguas infectadas, teniendo particular cuidado con las lagunas y aguas estancadas para darles corriente, o terraplenar las zonas de donde emanasen vapores infectos que podrían ser la causa de la conta-

${ }^{214}$ Novísima Recopilación, VII,30,14.

${ }^{215}$ Véase las Reglas sobre la policía de la salud pública que se han de observar por la Suprema Junta de gobierno de Medicina, contenidas en las "Ordenanzas del Real Colegio de Medicina de Madrid" y suprema Junta, aprobadas por Carlos IV, por el capítulo 16 de la Real Cédula de 15 de noviembre de 1796 (Novísima Recopilación, VII,40,5). En particular, se atendía a los "efluvios, emanaciones, vapores y miasmas" procedentes de sustancias animales, vegetales o minerales corrompidas que se difundían por el aire transmitiendo enfermedades infecciosas (Ibíd., VII, $40,5, \$ 1$ ). Asimismo, se ordenaba sepultar a los cadáveres a suficiente profundidad, que no se expusieran en zonas públicas cuando estaban en estado de putrefacción y que se efectuasen las limpiezas necesarias en las horas, y estaciones donde fuese más difícil que se propagaran "las miasmas que despiden los cadáveres" (Ibíd., VII,40,5, \$2). Para proteger la salud pública, se prohibía que se situasen dentro de la Corte o de las poblaciones determinadas fábricas que pudieran alterar o contaminar la atmósfera (Ibíd., VII,40,5, \$3). Del mismo modo, los edificios relacionados con la salud pública como hospitales, hospicios, cárceles, matadero, etc., necesitaban para su construcción el dictamen de la suprema Junta, teniéndose en cuenta las condiciones del terreno, la ventilación y la limpieza (Ibíd., VII,40,5, \$4). Especial atención se prestaba a las medidas para evitar la propagación de enfermedades contagiosas (Ibíd., VII,40,2,3 y 5, \$5), a los alimentos y bebidas de mala calidad o adulterados o en mal estado (Ibíd., VII,40,5, $\$ \$ 6$ y 7) y a los perjuicios que causaba a la salud conservar los alimentos y bebidas en vasijas que no fuesen las adecuadas (Ibíd., VII,40,6). Para Jordano Fraga "al reconocerse la salud pública como un interés público tutelable", cualquier actividad lesiva no era ya una cuestión por resoolver entre dos propietarios (como sucedía en épocas anteriores), sino que "la autoridad administrativa aparecerá como sujeto de la relación, en posición de supremacía en orden a la eficaz salvaguardia del bien colectivo tutelado" [Jordano FraGA, Jesús, cit. (n. 2), p. 30].

${ }^{216}$ Novisima Recopilación, VII,40,7. 
minación del aire con especiales precauciones para los trabajadores que llevasen a cabo estas tareas ${ }^{217}$.

\section{BiBLIOGRAFÍA}

Abellán Pérez, Juan - García GuZmán, Ma del Mar (editores), Ordenanzas Municipales del Castillo de Garcimuñoz de 1497 (Departamento de Historia medieval, Servicio de Publicaciones, Universidad de Cádiz, Cádiz, 1985).

AlLARD, Georges, Legislation romaine sur les eaux (tesis doctoral, Lille, Imprimerie L. Danel, 1874).

ARdemans, Teodoro, Declaración y extensión sobre las Ordenanzas que escribió Juan de Torija, Aparejador de obras Reales y de las que se practican en las Ciudades de Toledo y Sevilla, con algunas advertencias, a los Alarifes y Particulares, y otros capitulos añadidos a la perfecta inteligencia de la materia, que todo se cifra en el Gobierno Político de las Fábricas (Madrid, Plácido Barco López, 1796).

Ardemans, Teodoro, Ordenanzas de Madrid y otras diferentes que se practican en las ciudades de Toledo y Sevilla, con algunas advertencias, a los Alarifes y Particulares, y otros Capitulos añadidos a la perfecta inteligencia de la materia, que todo se cifra en el Gobierno Político de las Fábricas, aumentado en esta última impresión con el Bando sobre incendios, publicado en Madrid el 8 de noviembre del año de mil setecientos noventa (Madrid, Imprenta de Don Joseph Doblado, 1791).

Arndts Ritter von Arnesberg, Ludwig, Lehrbuch der Pandekten (7a edición, Stuttgart, 1872; 9a edición, Stuttgart, 1877, reimp. anastática, Frankfurt am Main, 1983; $10^{a}$ edición, Stuttgart, 1879, 14a edición, Stuttgart, 1889; trad. italiana de F. Serafini, 3 vols., Bologna, 1877-1880, I, $3^{\text {a }}$ edición, Bologna, Tipi Fava e Garagnani, 1880).

AYMARD, Maurice, Irrigations du Midi de l'Espagne: études sur les grands travaux hydrauliques et le régime administratif des arrosages de cette contrée (Paris, 1964).

BARCELÓ, Miquel (coordinador), The design of irrigation systems in al-Andalus (Barcelona, Universitat Autònoma de Barcelona, 1998).

Belando, Juan, Estudio sobre el río Segura y la huerta de Murcia (Murcia, 1878).

Blanco EsQuivias, Beatriz, Teodoro Ardemans y su entorno en el cambio de siglo (16611726). Aspectos de la arquitectura y el urbanismo madrileños de Felipe II a Carlos III (Madrid, Universidad Complutense, 1991).

Callies, David L. Historic Preservation Law in the United States (Washington, D. C., Enviromental Law Institute, 2002).

CUVILlier, Jean Pierre, Lirrigation dans la Catalogne médiévale et moderne, en Mélanges de la Casa de Velázquez, 20 (1984).

Delgado, Pedro, La real acequia del Jarama (Madrid, Ministerio de Obras Públicas, Transportes y Medio Ambiente, Centro de Publicaciones, 1995) 2 vols.

De Diego Velasco, María Teresa, Las Ordenanzas de las Aguas de Granada, en En la España Medieval, 4 (1984).

de la Cruz Aguilar, Emilio, Ordenanzas del Común de la villa de Segura y su Tierra de 1580 (Instituto de Estudios Giennenses de la Diputación Provincial, 1980).

${ }^{217}$ Ibíd., VII,40,7 nota 5. 
DE TORIJA, Juan, Tratado breve sobre las ordenanzas de la villa de Madrid y policía de ella (Madrid, 1661).

Falbo, Aníbal José, Derecho ambiental (La Plata, Librería Editora Platense, 2009).

Federovisky, Sergio, Historia del medio ambiente (Buenos Aires, editorial Capital Intelectual, 2007).

Fernández Gimeno, José Pascual - Gamborino Martínez, Gloria, en Reyes López, María José (coordinador), Derecho ambiental español (Valencia, Tirant lo Blanch, 2001).

Garrabou Segura, Ramón - Naredo Pérez, José Manuel (editores), El agua en los sistemas agrarios: una perspectiva histórica (Madrid, Fundación Argentaria, Visor Distribuciones, 1999).

Gerez Kraemer, Gabriel M., La distinción en España entre las aguas públicas y las aguas privadas desde el derecho romano hasta nuestros días, en FERNÁNDEZ DE BUJÁN, Antonio - Gerez Kraemer Gabriel - Malavé Osuna, Belén (coeditores), Hacia un Derecho administrativo y Fiscal romano (Madrid, Dykinson, 2011).

GuICK, T. F., Regadio y sociedad en la Valencia medieval (Valencia, 1988).

Gómez Rojo, María Encarnación, Precedentes de protección medioambiental en el Derecho Histórico Español de la Edad Moderna, en Arancibia MatTar, Jaime Martínez Estay, José Ignacio (coords.), La primacía de la persona. Estudios en homenaje al Profesor Eduardo Soto Kloss (Santiago de Chile, LegalPublishing, AbeledoPerrot, 2009).

GonZÁlez ArCe, José Damián, Ordenanzas de la ciudad de Murcia (1536) (Universidad de Murcia, Servicio de Publicaciones, Murcia, 2000).

GonzÁlez de Molina, Manuel, Historia y medio ambiente (Madrid, Eudema, 1993).

Gual Camarena, Miguel, Estudio histórico-geográfico sobre la Acequia Real del Júcar (Valencia, Instituto de Geografía, Institución Alfonso El Magnánimo, Diputación Provincial de Valencia, Acequia Real del Júcar, 1979).

Hornborg, Alf - McNeill, J. R - Martínez-Alier, Joan (editores), Rethinking Environmental History: World-System History and Global Environmental Change (Lanham, Altamira Press, 2007).

Jaquenod Martínez, Silvia Susana, El Derecho ambiental y sus principios rectores (Madrid, Universidad Complutense, 1989).

JaQUenod Martínez, Silvia Susana, Derecho ambiental (Dykinson, Madrid, $1^{\mathrm{a}}$ edición, 2002; 2a ed. 2004).

JoRDANO FRAGA, Jesús, La protección del derecho a un medio ambiente adecuado (Barcelona, Bosch, 1995).

Ladero Quesada, Miguel Ángel y Galán Parra, Isabel, Las ordenanzas locales en la Corona de Castilla como fuente histórica y tema de investigación (siglos XIII al XVIII), en Anales de la Universidad de Alicante. Historia Medieval, 1 (1982).

López Gómez, A., Estudios sobre los regadíos valencianos (Valencia, Universitat de Valéncia, 1989).

Llauradó, A., Tratado de aguas y riegos (Madrid, Imprenta de Moreno y Rojas, 1884), 2 vols.

Llodrà Grimalt, Francesca, Lecciones de Derecho ambiental civil (Palma, Universitat de les Illes Balears, 2008).

Martín Mateo, Ramón, Tratado de Derecho Ambiental (Madrid, Trivium, 1991, I, $3^{\text {a }}$ edición revisada y puesta al día, Cizur Menor, Aranzadi, 2003). 
Martínez Ruiz, Enrique - de Pazzis Pi Corrales, Magdalena, Protección y seguridad en los sitios reales desde la Ilustración al Liberalismo (Publicaciones Universidad de Alicante, Alicante, 2010).

MazzA, Alfredo, Dei diritti sulle acque. Manuale teorico pratico (Roma, Athenaeum, 1913).

Navascués Palacios, Pedro, Introducción al desarrollo urbano de Madrid hasta 1830, en Madrid, testimonios de su historia (Museo Municipal, 1979).

Recopilacion delas leyes destos reynos hecha por mandado [...] del Rey don Philippe segundo [...]: contienensen [...] las leyes hechas hasta fin del año de mil y quinientos y sesenta $y$ ocho, excepto las leyes de partida y del fuero y del estilo, y también van en el las visitas de las audiencias (Alcalá de Henares, Casa de Andrés de Angulo, 1569).

Novísima Recopilación de las Leyes de España (edición facsímil, Boletín oficial del Estado, Madrid, 1976; 2a edición, 1993).

Ordenanzas de Granada de 1552 (edición facsímil con introducción de López Nevot, José Antonio, Granada 2000).

Ordenanzas de la muy noble y muy leal ciudad de Málaga de 1611 (edición facsímil, Málaga, 1996).

Pérez Bustamante, Rogelio - Baró Pazos, Juan, El Gobierno y la Administración de los pueblos de Cantabria, I: Liébana (Diputación regional de Cantabria, Universidad de Cantabria, Santander, 1988).

Plocque, Alfred-Henri, Du régime legal des eaux servant a l'alimentation de la ville de Rome (tesis doctoral, Paris, Typographie de Henri Plon, Imprimeur de l'Empereur, 1868).

Porras Arboledas, Pedro Andrés, El Ordenamiento de Penas de Cámara de Enrique III (1400). Un nuevo manuscrito, en Cuadernos de Historia del Derecho, 10 (2003).

Reglamento de Pesca y Navegación de 27 de agosto de 1763 (edición del Ministerio de Agricultura, Pesca y Alimentación de 1982).

Riv, Manuel, El agua y su aprovechamiento en las ciudades y villas catalanas medievales, en El món urbà a la Corona d'Aragó del 1137 als decrets de nova planta: XVII Congrés d'Història de la Corona d'Aragó, Barcelona-Lleida, 7-12 setembre del 2000 (Actes, Barcelona, Edicións Universitat de Barcelona, 2003), I.

Roche, Catherine, L'essentiel du droit de l'environnement (Paris, Gualino, 2009).

Ruiz, Salvador - AlburquerQue, Juan Miguel, Algunas notas referentes a la experiencia administrativa romana de protección de los recursos naturales, en FERNÁNDEZ DE Buján, Antonio - Gerez Kraemer Gabriel - Malavé Osuna, Belén (coeditores), Hacia un Derecho administrativo y Fiscal romano (Madrid, Dykinson, 2011).

Ruiz-Funes García, Mariano, Derecho consuetudinario y economía popular de la provincia de Murcia, con "Prólogo" de Cerdá Ruiz-Funes, Joaquín (Murcia, Academia Alfonso X el Sabio, reimp. 1983).

Solidoro Maruotti, Laura, La tutela dell'ambiente nella sua evoluzione storica. L'esperienza del mondo antico (Torino, Giappichelli, 2009).

TAsso YzQuierdo, Rafael, Algunos datos sobre la historia, descripción y actuación de la Acequia Real del Júcar (Valencia, 1945; 2a edición, 1964).

Teira VILAR, Francisco Javier, El régimen jurídico de aguas en el Llano de Lérida (siglos XII a XVIII), con "Prólogo" de Font i Rius, Josep M. (Barcelona, Universidad de Barcelona, Facultad de Derecho, Cátedra de Historia del Derecho Español, 1977).

The Oldest Code of Laws in the World: The Code of Laws Promulgated by Hammurabi, 
King of Babylon, B. C. 2285-2242, trad. de Johns, C. H. W. (Edinburgh, T. \& T. Clark, 1926; New Jersey, The Lawbook Exchange, LTD., 2000).

URTEAGA, Luis, Ideas medioambientales en el siglo XVIII (Madrid, Akal, 1997).

Vergara Blanco, Alejandro, Derecho de Aguas (Editorial Jurídica de Chile, Santiago de Chile, 1998), I.

Vergara Blanco, Alejandro, Contribución a la historia del derecho de aguas, II: Fuentes y principios del derecho de aguas español medieval y moderno, en Revista de Derecho de Minas y Aguas, 2 (1991).

Viguri Perea, Agustín, Globalización y defensa del medio ambiente en el derecho privado: aplicación del principio "quien contamina paga" y régimen de la responsabilidad civil objetiva: derecho español, europeo, norteamericano y japonés (Madrid, Colegio de Registradores de la Propiedad y Mercantiles de España, 2009).

Zambrana Moral, Patricia, La protección de las aguas frente a la contaminación y otros aspectos medioambientales en el Derecho romano y en el Derecho castellano medieval, en Revista de Derecho de la Pontificia Universidad Católica de Valparaíso, 37 (2० semestre, 2011).

Zambrana Moral, Patricia, Introducción a la Historia del Derecho medioambiental catalán: la salubridad de las aguas en las fuentes juridicas de Barcelona y Tortosa en la Edad Media y Moderna, en Revista de Dret Històric Català, 11 (Barcelona, 2011, en prensa). 
